ARTICLE

\title{
Earliest Olduvai hominins exploited unstable environments 2 million years ago
}

\author{
Julio Mercader (1) 1,2凶, Pam Akuku 3,4, Nicole Boivin (10) 1,2,5,6, Revocatus Bugumba7, Pastory Bushozi ${ }^{8}$, \\ Alfredo Camacho ${ }^{9}$, Tristan Carter (10 ${ }^{10}$, Siobhán Clarke (1) ${ }^{1}$, Arturo Cueva-Temprana (1) ${ }^{2}$, Paul Durkin ${ }^{9}$, \\ Julien Favreau (iD ${ }^{10}$, Kelvin Fella ${ }^{8}$, Simon Haberle (iD ${ }^{11}$, Stephen Hubbard (iD) ${ }^{1 凶}$, Jamie Inwood ${ }^{1}$, Makarius Itambu ${ }^{8}$, \\ Samson Koromo ${ }^{12}$, Patrick Lee ${ }^{13}$, Abdallah Mohammed ${ }^{8}$, Aloyce Mwambwiga ${ }^{1,14}$, Lucas Olesilau ${ }^{12}$,

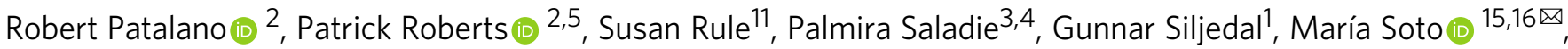 \\ Jonathan Umbsaar ${ }^{1} \&$ Michael Petraglia (1D 2,5,6
}

Rapid environmental change is a catalyst for human evolution, driving dietary innovations, habitat diversification, and dispersal. However, there is a dearth of information to assess hominin adaptions to changing physiography during key evolutionary stages such as the early Pleistocene. Here we report a multiproxy dataset from Ewass Oldupa, in the Western PlioPleistocene rift basin of Olduvai Gorge (now Oldupai), Tanzania, to address this lacuna and offer an ecological perspective on human adaptability two million years ago. Oldupai's earliest hominins sequentially inhabited the floodplains of sinuous channels, then river-influenced contexts, which now comprises the oldest palaeolake setting documented regionally. Early Oldowan tools reveal a homogenous technology to utilise diverse, rapidly changing environments that ranged from fern meadows to woodland mosaics, naturally burned landscapes, to lakeside woodland/palm groves as well as hyper-xeric steppes. Hominins periodically used emerging landscapes and disturbance biomes multiple times over 235,000 years, thus predating by more than 180,000 years the earliest known hominins and Oldowan industries from the Eastern side of the basin.

\footnotetext{
${ }^{1}$ University of Calgary, Alberta, Canada. ${ }^{2}$ Max Planck Institute for the Science of Human History, Jena, Germany. ${ }^{3}$ Institut Català de Paleoecologia Humana i Evolució Social (IPHES), Tarragona, Spain. ${ }^{4}$ Àrea de Prehistòria, Universitat Rovira i Virgili (URV), Tarragona, Spain. ${ }^{5}$ School of Social Science, University of Queensland, Saint Lucia, QLD, Australia. ${ }^{6}$ National Museum of Natural History, Smithsonian Institution, Washington, DC, USA. ${ }^{7}$ Ministry of Natural Resources and Tourism, Dar es Salaam, Tanzania. ${ }^{8}$ University of Dar es Salaam, Dar es Salaam, Tanzania. ${ }^{9}$ University of Manitoba, Winnipeg, Manitoba, Canada. ${ }^{10}$ McMaster University, Hamilton, Ontario, Canada. ${ }^{11}$ Australian National University, Canberra, ACT, Australia. ${ }^{12}$ University of Iringa,

Iringa, Tanzania. ${ }^{13}$ University of Toronto, Toronto, Ontario, Canada. ${ }^{14}$ National Natural History Museum, Arusha, Tanzania. ${ }^{15}$ Madrid Institute for Advanced

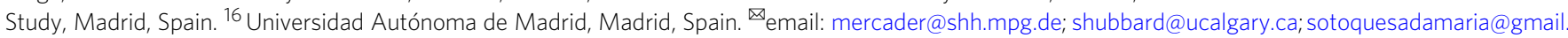
com
} 
$\mathrm{H}$ ominins underwent major biological transitions in the early Pleistocene, along with an increased reliance on stone tool use ${ }^{1}$, overall dietary diversification ${ }^{2-6}$, and longdistance dispersal ${ }^{7-9}$. The behavioural context of these shifts remains elusive due to a dearth of high-resolution chronostratigraphic and environmental datasets in direct association with Oldowan remains, available only for a small number of sites ${ }^{10-17}$. Furthermore, extrapolating offsite palaeoecological proxies from penecontemporaenous boreholes and lake-drilling sequences ${ }^{18}$ has limited applicability for understanding localized land use, the synchronous/diachronous occupation of varied terrestrial environments, and targeted habitat exploitation by Oldowan hominins.

Palaeoenvironmental reconstruction from sites 2.6 to $1.9 \mathrm{Ma}$ has relied on indirect approximations of past vegetation from fauna and/or stable isotopes ${ }^{13-17,19,20}$, denoting variably open grassland and forest mosaics in fluvial settings often from restricted stratigraphic intervals ${ }^{21,22}$. Our research reconciles the earliest Oldowan stone tools from Oldupai Gorge, a key complex for the study of hominin lifeways ${ }^{23,24}$, with multiproxy datasets in direct association with stratified archaeological and fossil assemblages, recording episodic exploitation of the same place in varied geomorphic contexts and sedimentary deposits. This dataset stands as a model of cross-disciplinary research to clarify the environmental context of early Oldowan sites. Here we examine hominin behavior in association with faunal and plant communities and provide evidence of vegetation physiognomy and cover from phytolith analysis and palynology, isotopic nalkane values from plant waxes, stable isotopes from enamel, and regional fires from microcharcoal concentrations.

\section{Results}

Stratigraphy and archaeology. The Ewass Oldupa site (Geological Locality 63, Fig. 1) $)^{23}$ is located $350 \mathrm{~m}$ northeast of Geological Locality 64, where a dentally complete maxilla and lower face of Homo habilis $(\mathrm{OH} 65)^{22}$ was recovered from strata dated to $\sim 1.82 \mathrm{Ma}^{25,26}$. At Ewass Oldupa, we exposed a thick sedimentary sequence with ages bracketed by existing ${ }^{40} \mathrm{Ar} /{ }^{39} \mathrm{Ar}$ dates of geochemically fingerprinted tuffs ${ }^{26,27}$, which was further constrained at six localities along a $2 \mathrm{~km}$ transect (Supplementary Fig. 1, Table 1). The lowermost stratigraphic unit is the Naabi ignimbrite of the Ngorongoro Formation ${ }^{18}$ (Figs. 1 and 2a). Above this sits the highly heterogeneous Coarse Feldspar Crystal Tuff compositional zone (CFCTcz) ${ }^{28}$ (Figs. 1 and 2c), including the Coarse Feldspar Crystal Tuff $(2.015 \pm 0.006 \mathrm{Ma})^{25}$. Lower Bed I starts with the deposition of a green waxy clay $^{29}$ and intercalated carbonate beds, indicating lake expansion $1 \mathrm{~km}$ further west and occurring earlier than previously recorded ${ }^{18,26-29}$ (Figs. 1-2e). Tuff IA $(\sim 2.0 \mathrm{Ma})^{18}$ (Figs. 1 and 2 f, g) contains characteristic Mgrich augite, reworked basement-derived detrital grains and CFCTcz materials ${ }^{25-28}$. Upper Bed I includes Tuff IB (1.848 \pm $0.003 \mathrm{Ma})^{25}$. Directly overlying this are waxy, green-brown claystones deposited during a period of high lake level (Figs. 1, $2 \mathrm{~h})$. Overlying these clays, a weakly stratified siltstone has the geochemical signature of Tuff IC $(1.832 \pm 0.003 / 1.848 \pm 0.008$ $\mathrm{Ma})^{22,25,26}$. Capping it, a weakly planar stratified sandstone is geochemically consistent with Tuff ID, identified elsewhere in the western gorge as the interval containing the remains of Homo habilis $(\mathrm{OH} 65)^{22,26}$. A thin bed with carbonate nodules and coarse-grained siliciclastic material is petrographically and geochemically identified as the Ng'eju Tuff $(1.818 \pm 0.006 \mathrm{Ma})^{25,26}$.

The geo-archaeological record through the Ewass Oldupa sequence shows evidence of human occupation $2.0-1.9 \mathrm{Ma}$ through rapidly shifting depositional environments that comprised meandering streams cutting across a volcaniclastic fan, followed by mass flow events, several transgression/regression lacustrine cycles, large and small prograding fluvial systems, with intercalated volcanism. Importantly, this record of hominin habitats predates, to our knowledge, the oldest fossiliferous and tool bearing deposits from the Eastern basin's locality of 'Douglas Korongo' (DK), which traditionally represented the earliest Oldowan presence in the region at $\sim 1.848 \pm 0.003 \mathrm{Ma}^{24,30,31}$.

Excavations at Ewass Oldupa recovered 1373 fossil specimens and 565 stone artefacts (Supplementary Table 1) showing consistent technological features from immediately post-Naabi to the base of Bed II. All knapping stages are present (Supplementary Table 1). Lithics derive from tabular, medium grained, grayish/whitish quartzite slabs that are clustered $\left(7 / \mathrm{m}^{2}\right)$ in discrete archaeo-stratigraphic assemblages $\left(7 / 40 \mathrm{~m}^{2}\right.$ ) (Figs. 3 and 4$)$. Flakes are the dominant product $(>60 \%)$, with spheroids and percussive materials being uncommon. There is no differential management of knapped surfaces, thus the technological systems do not follow hierarchical reduction strategies. Unidirectional and multidirectional knapping of cores was maintained within the constraints of natural shapes and angles for striking. Of the seven exploitation methods registered in 58 cores, multipolar-multifacial (number of cores $=19$, median number of extractions $=9)$, unipolar-longitudinal $(n=15$, median $=4)$, and orthogonal-bifacial $(n=13$, median $=5)$ dominate (Supplementary Fig. 2c). Intensity of lithic reduction is inferred from the minimum number of extractions per core, which ranges from two to 16 removals. Overall, the simplicity of Ewass Oldupa's technical repertoire is shared with other early Oldowan assemblages $6,10-12,14,15$ to include characteristics such as freehand hard hammer percussion and multi-facial reduction. Principal Component Analysis (PCA) (Supplementary Fig. 2a, b, Supplementary Fig. 3) conveys that Ewass Oldupa's Oldowan shares many technical attributes with Kanjera South ${ }^{14}$, Fejej ${ }^{11}$, and to some extent Frida Leakey Korongo Zinj (FLK Zinj) ${ }^{24}$. Significantly, several aspects of Ewass Oldupa's stone industries (unifacial and bipolar cores, number of extractions, flake size, angular fragments, and scarcity of percussion tools) best match the techno-typological profile seen in older Oldowan sites (Gona 10 and Gona 12$)^{15}$. In addition, PCA brings out a mosaic of early and classic Oldowan traits in Ewass Oldupa's lithics, which fall between the oldest Oldowan $>2 \mathrm{Ma}$ and younger assemblages $\leq 1.85 \mathrm{Ma}$, where spheroids abound. Likewise, this PCA, inclusive of 18 assemblages and comprising 11 technical variables ${ }^{15}$, demonstrates the outlier character of Lomekwi and its complete lack of affinity with Ewass Oldupa (Supplementary Figs. 2,3, Supplementary Table 2).

Comparison of geochemical fingerprinting of artefacts and regional rock outcrops (Supplementary Fig. 4) manifests hominins engaged in sourcing up to $12 \mathrm{~km}$ across the basin 32,33 while also exploiting quartzite locally, $400 \mathrm{~m}$ to the south (Naisiusiu). Macroscopically, four quartzite types of distinct colour, grain size, textural, and mineral composition were the preferred raw materials. Analysis of these varieties relative to reduction stage (Supplementary Fig. 2d) indicates that Oldowan groups targeted specific quartzite types for flakes, while other variants were for retouched tools. Spheroids and choppers were made of quartzite and ignimbrite, accessible from riverbeds.

Early Oldowan ecology at $\sim 2 \mathrm{Ma}$. The earliest Oldowan presence at Ewass Oldupa, dating to $2.03 \mathrm{Ma}$, is in a post-eruptive landscape, occurring on an expansive ignimbrite flow ${ }^{34}$ that buried the hydrological network of the southeast portion of the basin ${ }^{18}$ while draping over metamorphic inselbergs in the west (Figs. 1a and 2a, b). Initial hominin use, documented in the form of 10 stone tools, appears $1 \mathrm{~m}$ above the Naabi ignimbrite and $17 \mathrm{~m}$ below Tuff IA. It occurred after landscape stabilisation in association with a 


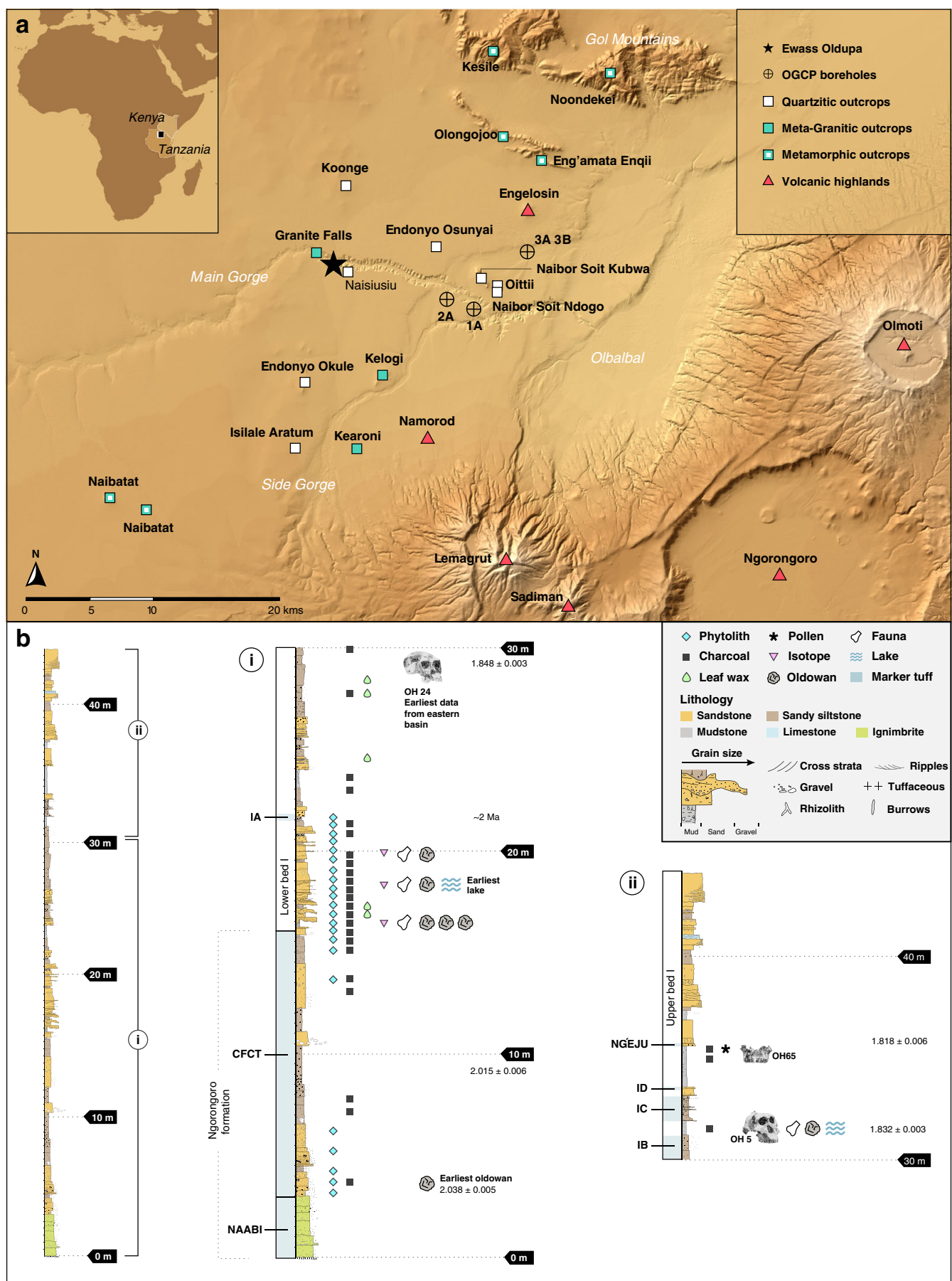

Fig. 1 Geographic and Stratigraphic Context. a Location map. Star symbol is for the site of Ewass Oldupa. Boreholes recently published ${ }^{18}$ are shown for reference. Major rock types potentially available for hominin exploitation throughout the region are also marked. b Single stratigraphic section from Ewass Oldupa, subdivided into two segments: lower (i) and upper (ii). Ngorongoro formation: the succession starts with the Naabi, a green-gray, quartz-trachyte welded tuff dated to $2.038 \pm 0.005 \mathrm{Ma}^{25}$. A thin red diamictite overlies the Naabi and separates it from a series of fining-upward sandstone-dominated units composed of mafic tephra (Fig. 2b) that is capped by siltstone. Ngorongoro formation, CFCT compositional zone: the strata are composed of reddishbrown sandstone, volcanic detritus, and tephra/siliciclastic diamictite ${ }^{28}$. (i) Lower Bed I-six units that upward fine from pebble-cobble conglomerate to cross-stratified sandstone are attributed to meandering river channels, below Tuff IA. Subsequently, a fine-grained silty sandstone that fines into waxy, green-brown claystone with carbonate nodules was deposited in a lake setting. Lastly, interbedded sandstone, siltstone, claystone, and tuffaceous beds record fluctuating environments from lacustrine to shallow lakeshore to floodplain with small fluvial channels. (ii) Upper Bed I-starts with Tuff IB, overlying waxy, green-brown claystone (Fig. 2H), and then Tuff IC. Capping the succession is a beige, weakly stratified sandstone that is geochemically consistent with Tuff $1 D^{22,25,26}$. Above this, the Ng'eju Tuff is encountered in a succession of fine-grained floodplain deposits. Additional stratigraphic information is presented in Fig. 5. 


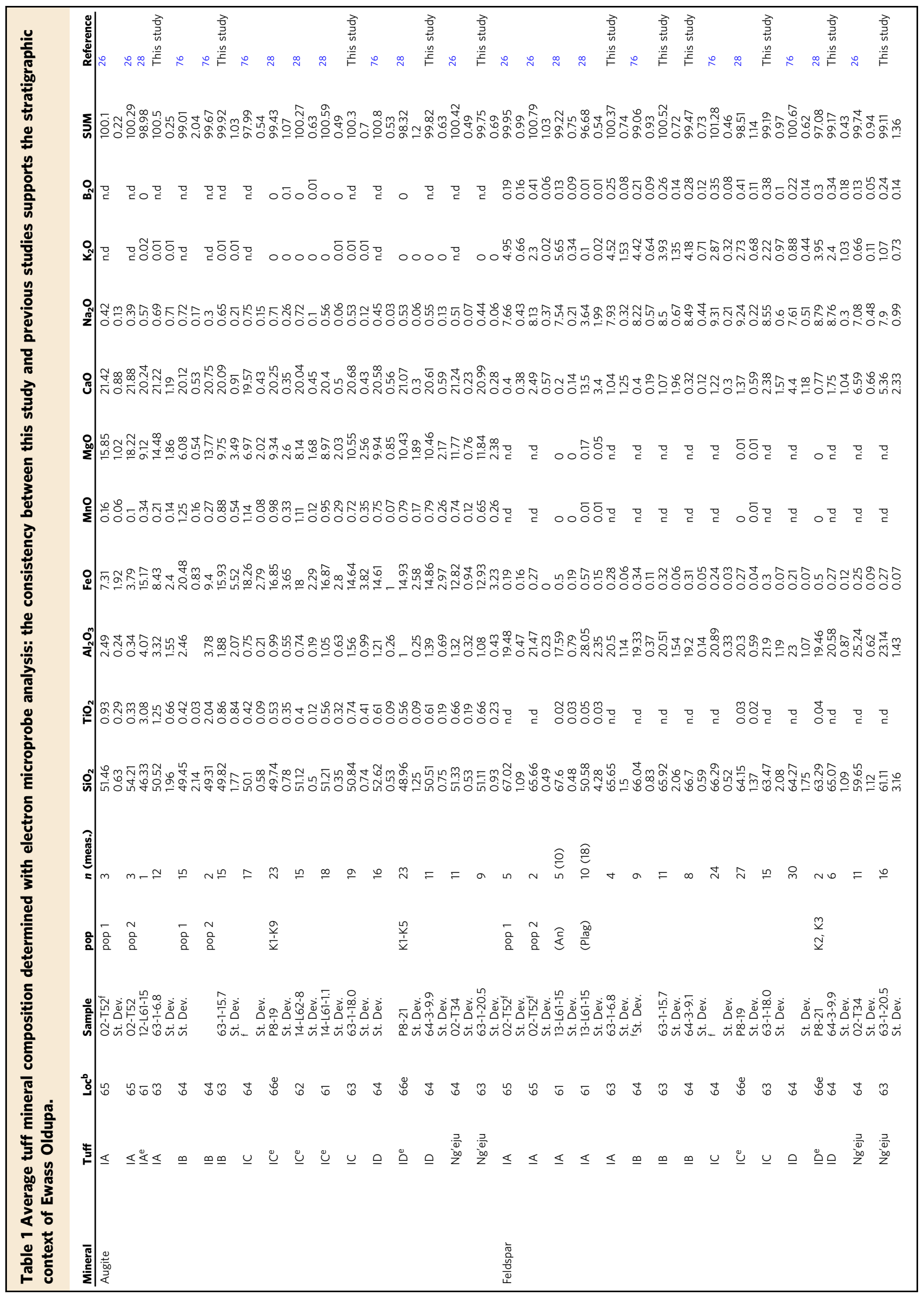




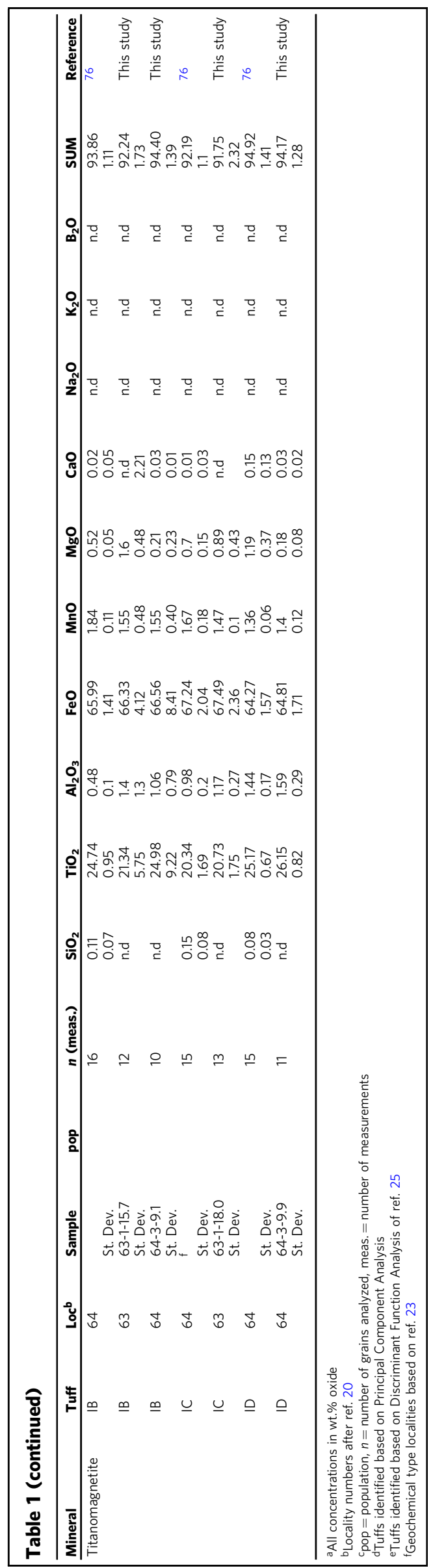

sinuous meandering river flowing northwest, as revealed in trench no. 7: the Naabi ignimbrite was the result of a high energy, catastrophic volcanic eruption and associated debris flow that drastically reshaped the landscape. After this, the volcanic events were less impactful and stable environments such as river channels and floodplains were able to develop. In a palaeogeographic setting where the quarzitic basement cropped out from the extruded pyroclastic flow and a fresh water channel ran through the distal part of a volcaniclastic fan, hominins periodically used the inselberg's foothill, within short distance of both materials for tools as well as water sources from the floodplain. The floral context is established by phytoliths (Figs. 5a, 6 and Supplementary Fig. 5), in which several fern types ${ }^{35-37}$ dominate assemblages (Fig. 6a, d, e), suggesting the existence of a fern meadow with minor woody growth and grasses; thus, pioneering bracken ferns facilitated the re-establishment of woody and grassy communities after a decrease in destructive volcanic events ${ }^{38}$.

During deposition of the CFCTcz $(2.015 \pm 0.006 \mathrm{Ma})^{25} \mathrm{Ma}$, rhizoliths in fine-grained units represent fluvial floodplain palaeosols in trench no.5 (Figs. 1, 2c, and 5). Mass flows did not allow prolonged quiescence, and laharic inundation buried synchronous woodland landscapes and Oldowan remains consisting of 12 lithics excavated $1 \mathrm{~km}$ west by other teams $\mathrm{s}^{39}$. Microcharcoals from wildfires peaked $\left(16,830\right.$ particles $\left./ \mathrm{cm}^{3}\right)$ (range through stratigraphic sequence $=72-16,830 / \mathrm{cm}^{3}$, median $=418 / \mathrm{cm}^{3}$ ) concomitantly with grass opal increase (Supplementary Fig. 5a, b). Great diversity in phytolith morphotypes denotes markedly uneven communities and quick shifts in plant dominance (Supplementary Fig. 5d, e).

Three additional Oldowan assemblages $(\sim 2 \mathrm{Ma})$ were found at the contact between the Ngorongoro Formation and Bed I, in association with a sinuous channel flowing east, and preserved $4.6 \mathrm{~m}$ below Tuff IA in trench no. 5 (Figs. 1, 2f, g, 3, and 5). The reconstructed environment is a short woodland mosaic as indicated by multiple proxies. For instance, plant wax isotopes, using the weighted average $\delta^{13} \mathrm{C}$ of $\mathrm{C}_{27}-\mathrm{C}_{33}$ for each individual sample and plotted using a sine-squared mixing model with endmember values of $-30 \%$ (pure $C_{3}$ ) and $-19 \%$ (pure $C_{4}$ ), reveal a depositional context of mosaics (Fig. 7a). One sample illustrates a $\mathrm{C}_{3}$-dominated environment likely in response to increased rainfall $\left(\delta^{13} \mathrm{C}\right.$ : $-27.9 \%$ ), whereas the other samples exhibit $\delta^{13} \mathrm{C}$ values more indicative of mixed environments, ranging from $\delta^{13} \mathrm{C}-22.6 \%$ to $\delta^{13} \mathrm{C}-24.6 \%$. This $\delta^{13} \mathrm{C}$ distribution for Ewass Oldupa is analogous to East African Acacia-Commiphora woodlands today. Another line of evidence indicative of woodland mosaics is stable isotopes from dental enamel: the entire analysed assemblage represents pre-Tuff IA times $\left(\delta^{13} \mathrm{C}:-7.2 \%\right.$ o to $1.6 \%$ ), pointing to herbivores consuming a mixture of $\mathrm{C}_{3}$ and $\mathrm{C}_{4}$ plants (Fig. 8). Although $\delta^{18} \mathrm{O}$ measurements can be influenced by a number of factors including precipitation, temperature, rainfall source, and physiology, the range obtained $\left(\delta^{18} \mathrm{O}:-4.7 \%\right.$ to $-0.2 \%$ ) is consistent with animals obtaining their water from a similar source and no clear distinctions between taxa are obvious (Fig. 8, Supplementary Fig. 6, and Supplementary Table 3). The range for $\delta^{18} \mathrm{O}$ could not be resolved to obligate or non-obligate drinking status. The enamel isotopic profile from Ewass Oldupa, in lowermost Bed I, resembles that from the younger woodlands in Bed II (Fig. 8), but contrasts with the open grassland profile prevailing in penecontemporaneous localities from western Kenya. Additional supporting evidence for a reconstructed palaeoenvironment of woodland/grassland mosaics is shown by phytoliths (Table 2, Figs. 5, 6, and Supplementary Fig. 5b), characterized by fluctuating woody dicot and grass outputs.

A fifth Oldowan assemblage includes stone tools and bones $4 \mathrm{~m}$ below Tuff IA $(\sim 2 \mathrm{Ma})$ on a transgressive lakeshore representing the earliest and furthest western expansion of palaeolake Oldupai, 


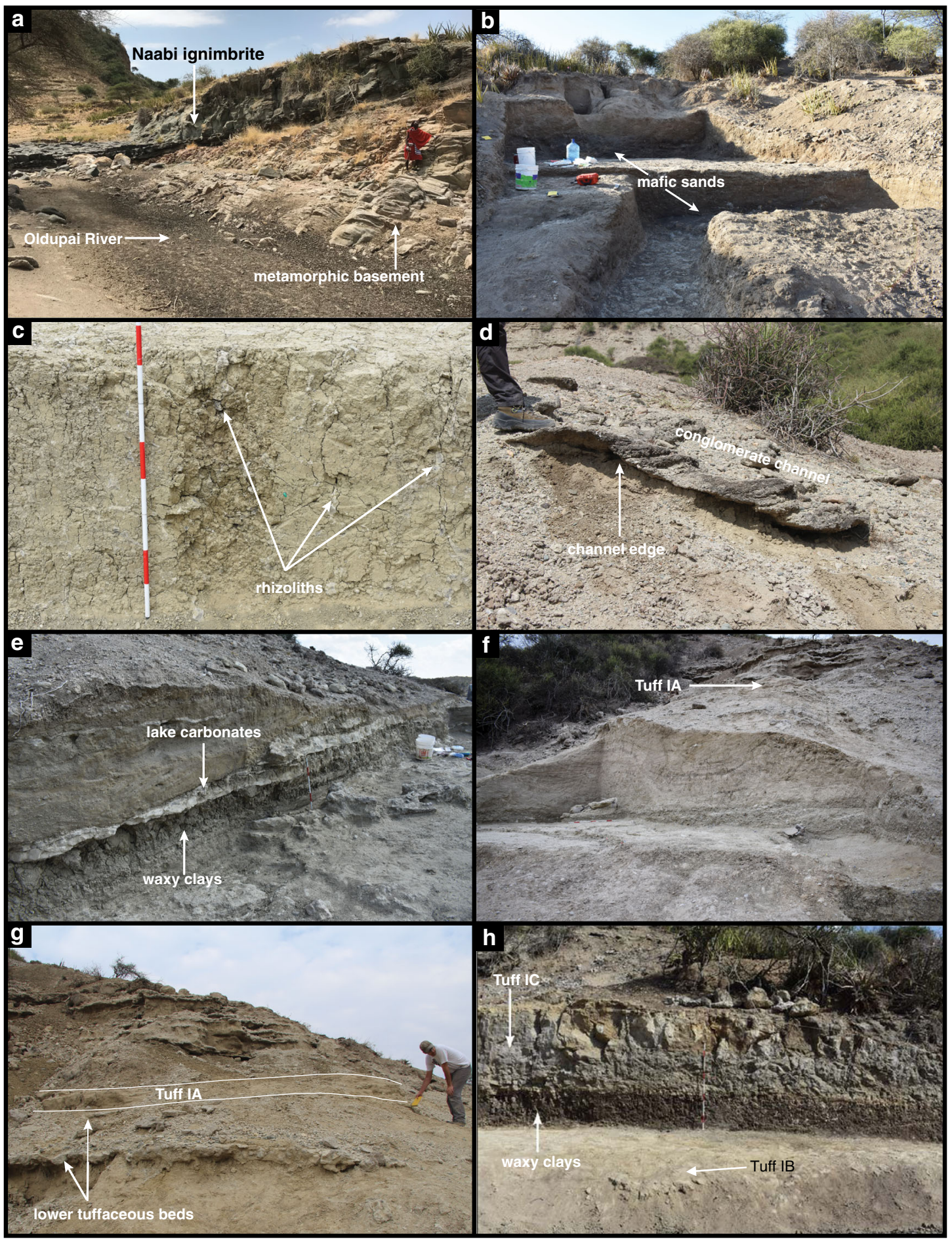

Fig. 2 Key stratigraphic horizons. a Ngorongoro formation: Naabi ignimbrite overlying metamorphic basement along the Oldupai River. b Ngorongoro Formation: Mafic sands immediately above the Naabi in trench 7. c Ngorongoro formation: CFCT compositional zone, trench 5, characterized by abundant rhizoliths. d Lower Bed I: conglomeratic channel fill deposit with trough-cross stratification dipping to the east. e Lower Bed I: waxy claystones from trench 3 capped by carbonate beds. $\mathbf{f}$ Lower Bed I: multi-storey fluvial channel belt deposits in trench 2, several meters beneath Tuff IA. (Metric pole on the ground for scale.) $\mathbf{g}$ Lower Bed I: Ewass Oldupa exposure of Tuff IA and underlying thin tuffaceous beds. $\mathbf{h}$ Upper Bed I: thick waxy claystone unit capping Tuff IB, and underlying Tuff IC. See Fig. 5 for further stratigraphic information.

as exposed in trench no. 3 (Figs. 1, 2e, 3, and 5). Taxonomically diverse fauna without hominin modification include Antelopini, Bovini, Hippotragini, and Tragelaphini (Supplementary Table 4, Supplementary Note 1), showing mixed habitats, in addition to water-dependent taxa. Phytoliths show a floristic tandem of woodlands and palms that epitomises the Oldowan lake margin occupations characteristic of Upper Bed I ${ }^{40-43}$ (Figs. 5-6, Table 2), representing proximity of fresh water and preferred hominin sources of raw materials. Further, the Oldowan stone tools from this horizon (Fig. 4e, f) are the earliest lithic evidence deposited in a waxy clay from a saline/alkaline lacustrine environment anywhere. 
a
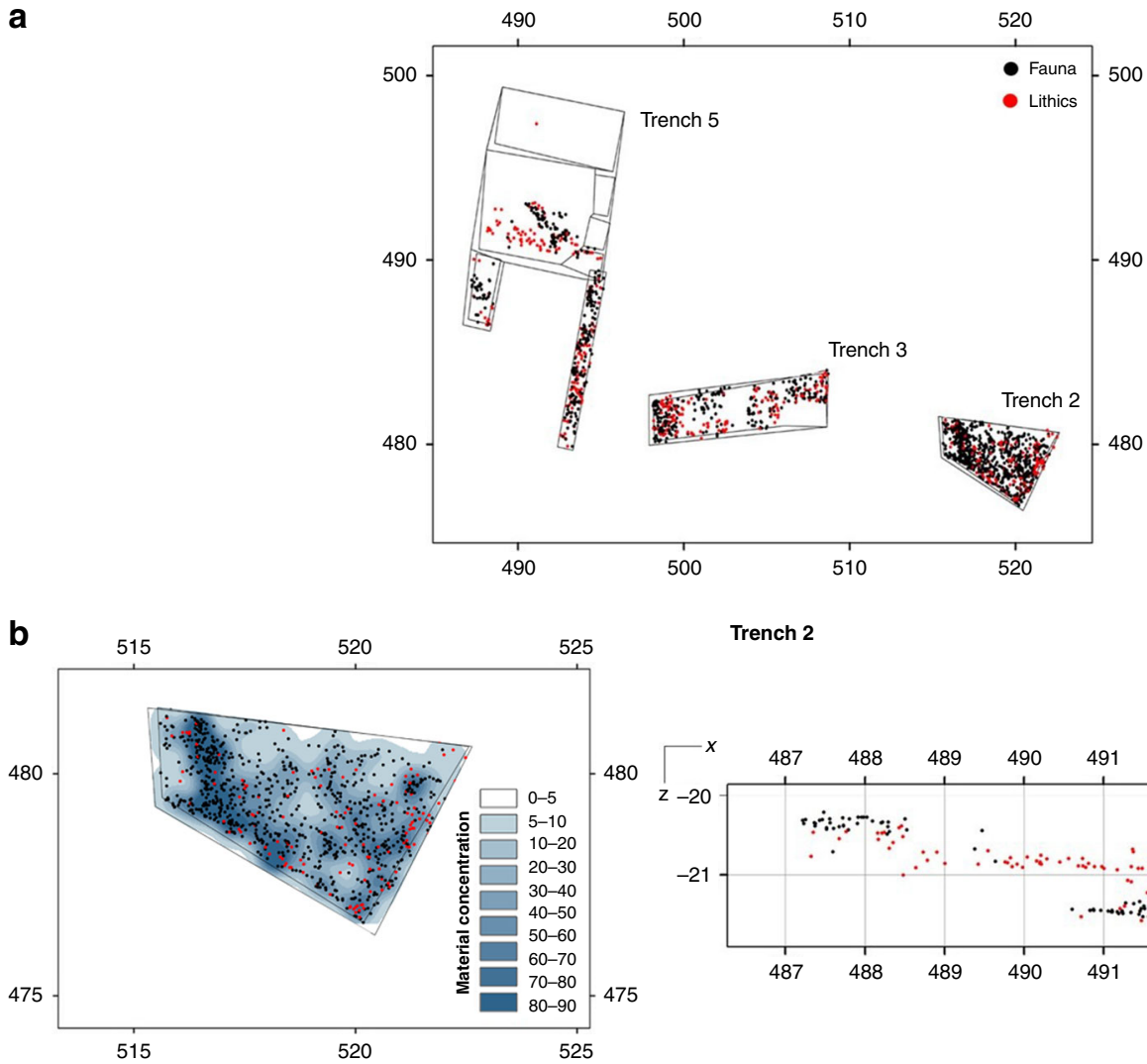

Trench 2
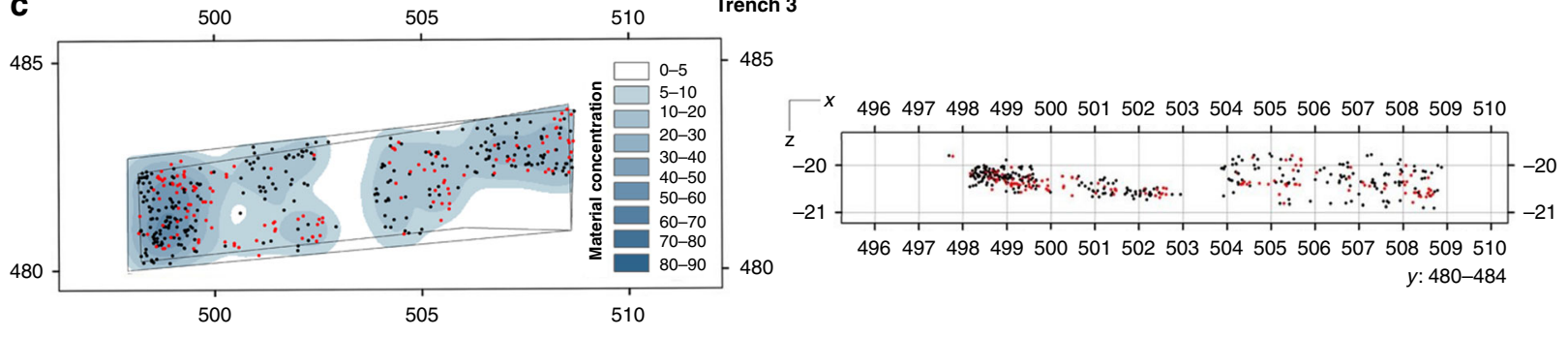

496497498499500501502503504505506507508509510 $y: 480-484$

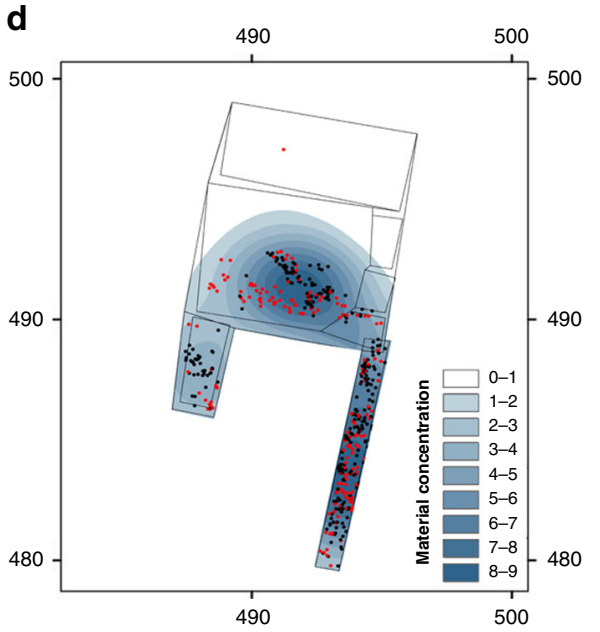

Trench 5

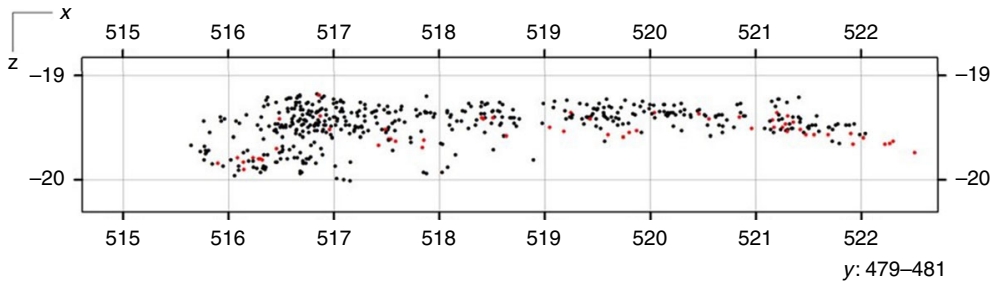

Fig. 3 Mapping of excavated materials. a Plotting of excavated lithics and fossil specimens. b-d Right: vertical projections of stone artifacts and bones show discrete archaeological horizons (axis units are in meters). Left: Kernel density analysis shows spatial variations in the accumulation of archaeological materials (densest in darkest blue). The stratigraphic position of trenches 2, 3, and 5 within the overall column is presented in Fig. 5. 


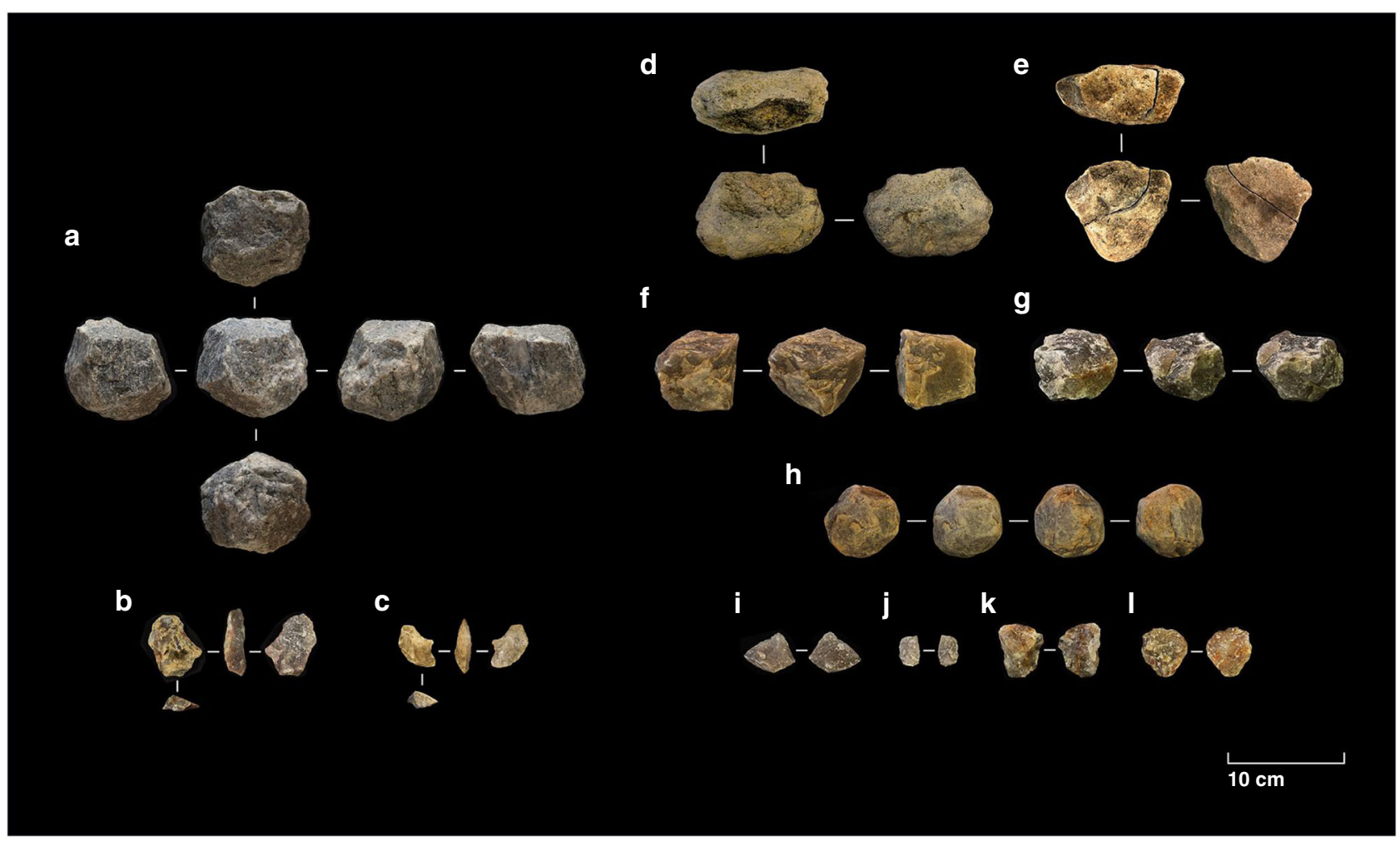

Fig. 4 Selection of stone tools from Ewass Oldupa. Ngorongoro Formation: earliest Oldowan, post Naabi, Trench 7: a Quartzite multipolar-multifacial core. b-c Quartzite flakes. Ngorongoro Formation, Contact CFCT compositional zone/Bottom of Bed I, Trench 5: d Ignimbrite chopping-tool. e Ignimbrite chopper. $\mathbf{f}$ Quartzite unipolar longitudinal core. $\mathbf{g}$ Quartzite multipolar-multifacial core. Lower Bed I: earliest lake expansion, Trench 3: $\mathbf{h}$ Quartzite spheroid. i Quartzite flakes. Lower Bed I: prograding fluvial system below Tuff IA, Trench 2: j-I Quartzite flakes.

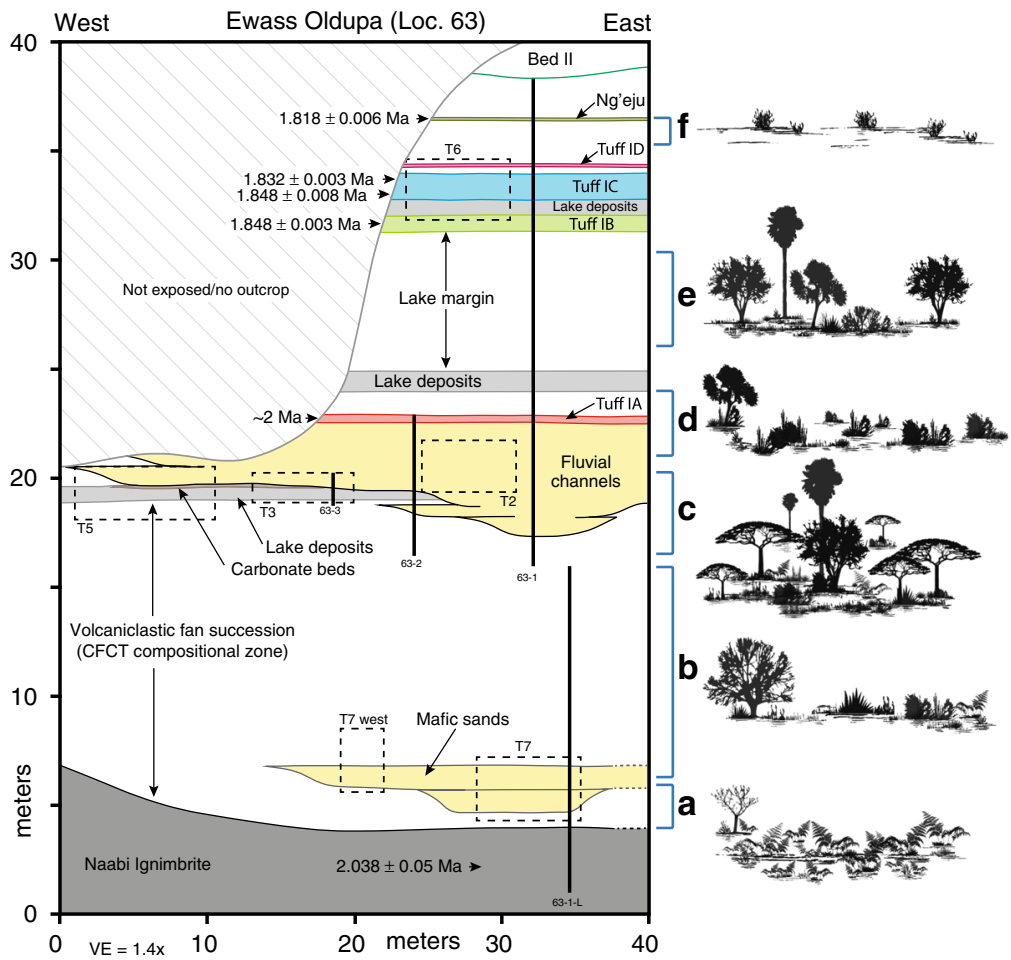

Fig. 5 Outcrop geometry, stratigraphic architecture, and idealized vegetation at Ewass Oldupa. Location of measured stratigraphic sections and excavation trenches. The details of section 63-1-L and 63-1 are presented in Fig. 1b. Artist rendering of plant communities over time: a Post-eruptive, fern meadow. b CFCT mosaics. c Woodland with palms and ferns. d Grasslands coeval with Tuff IA. e Open woodland. f Asteraceae-dominated scrub. 

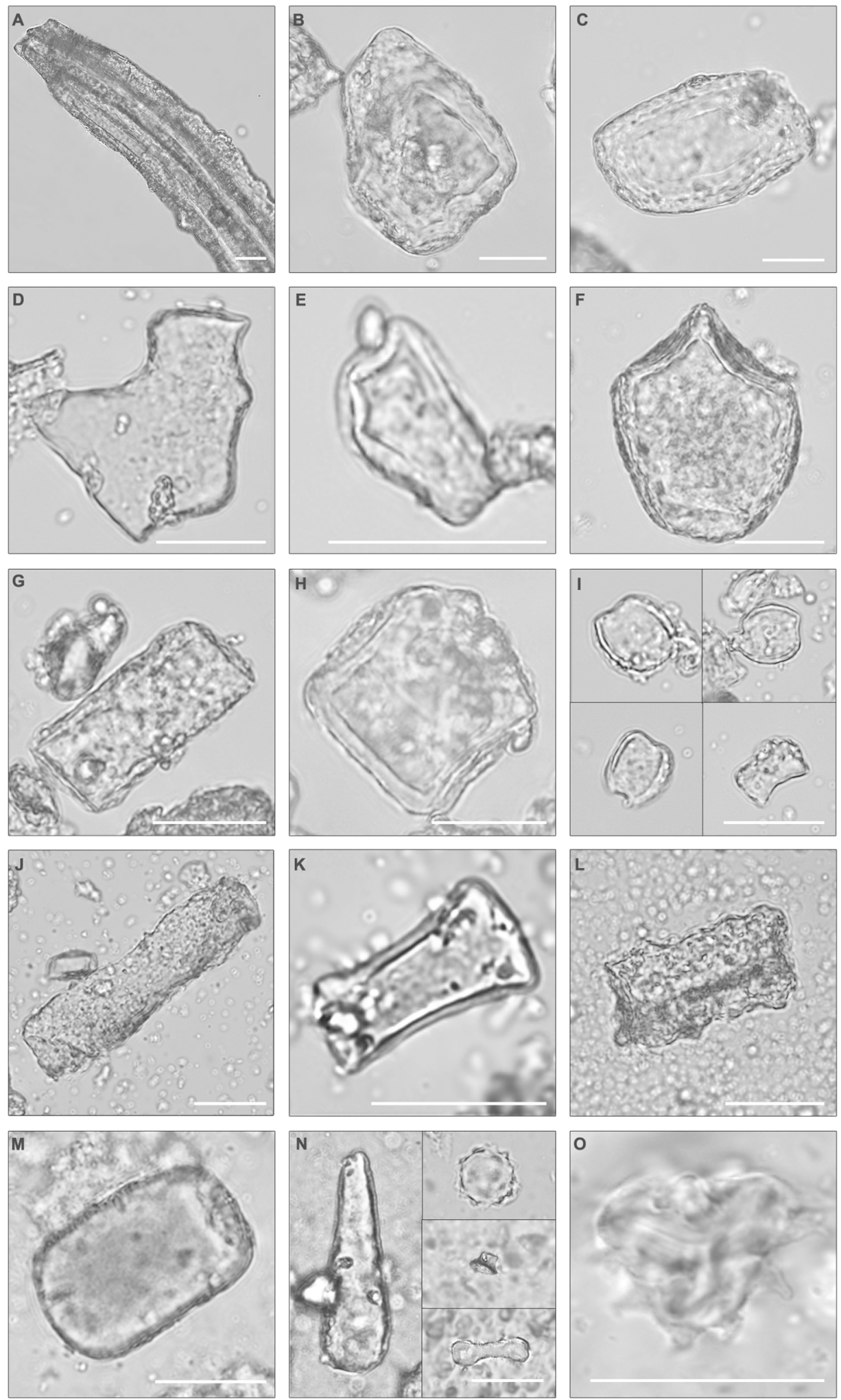

Fig. 6 Photomicrographs of selected phytoliths and pollen from Bed I. a Large tabular sulcate cf. Pteridaceae. b, c Blocky phytoliths from woody dicots. d Epidermal piece cf. Pteridaceae. e Tabular bifid cf. Pteridaceae (e.g. Cyrtomium). f Bulliform, Poaceae. g Tabular. h Shield cf. Solanaceae. i Saddle, short, Chloridoideae. j Tabular scrobiculate. $\mathbf{k}$ Tabular strangulated cf. Salvadora. I Tabular sinuate from woody dicot. $\mathbf{m}$ Blocky from woody dicot. $\mathbf{n}$ Left. Clavate from woody dicot. Right. Upper: globular echinate, Arecaceae. Middle: Tower, Poaceae. Bottom: Bilobate, long, convex, Poaceae. o Asteraceae pollen from Upper Bed I, immediately underneath the Ng'eju Tuff. Pollen concentration = 2649; C3 Ret. Lamiaceae/Convolvulaceae, 101; Asteraceae, 72; Rutaceae, 2. All scale bars $=25 \mu \mathrm{m}$. 

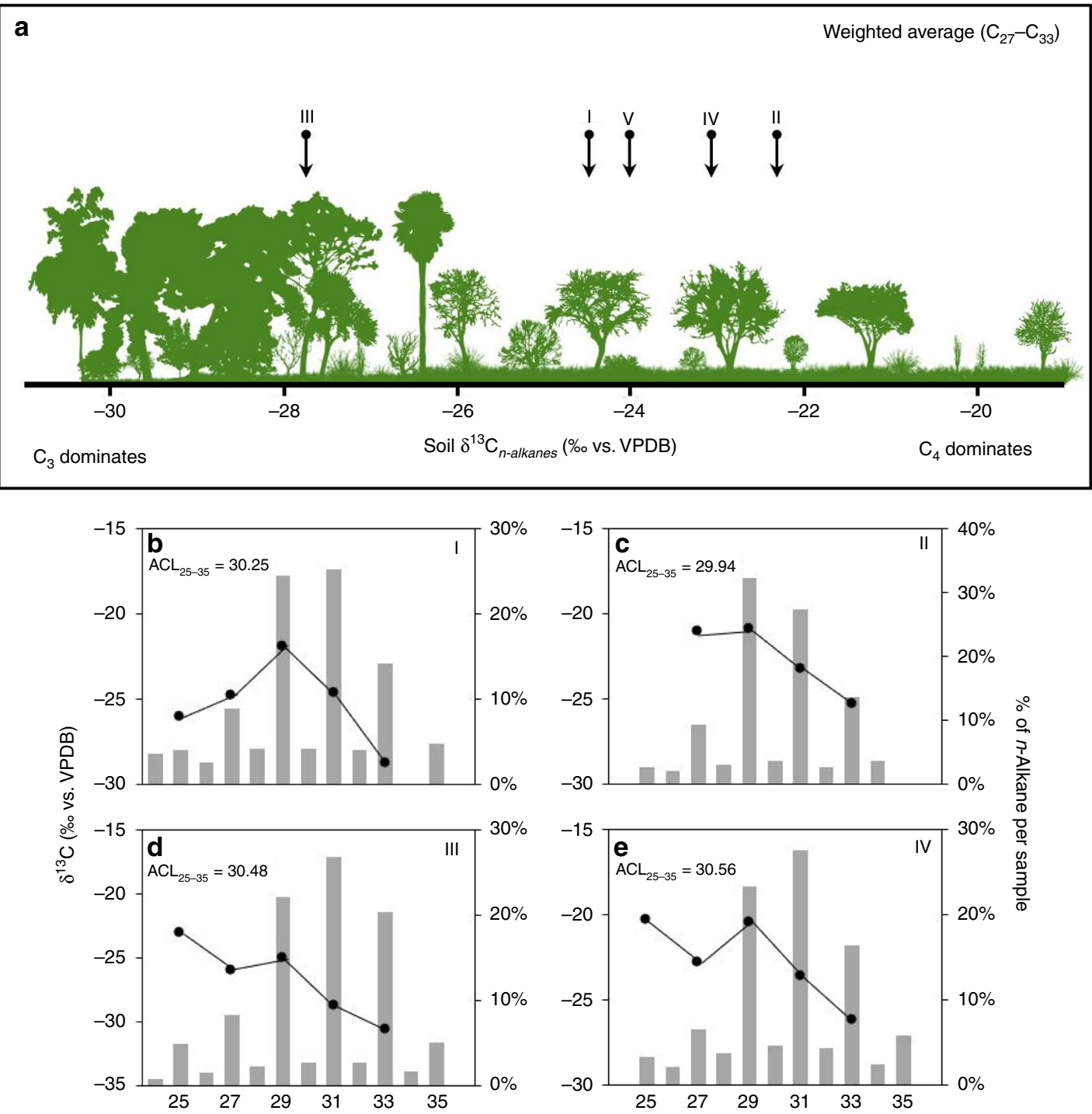

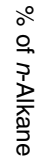

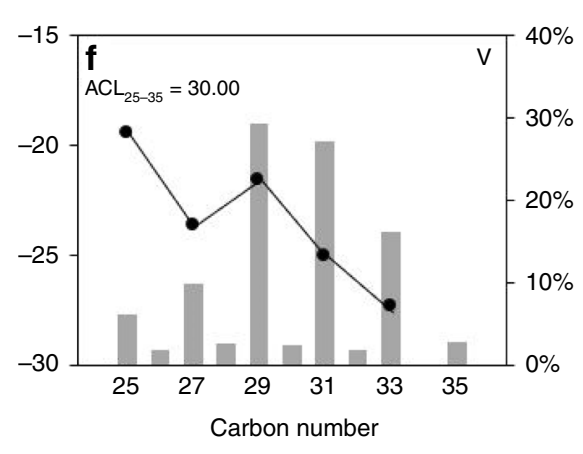

Fig. 7 Plant wax biomarkers. a Plant landscape reconstruction using $\delta^{13} \mathrm{C}$ of the weighted mean average of the $C_{27}-C_{33} n$-alkanes. A sine-squared mixing model with end-member values of $-30 \%$ (for pure $C_{3}$ ) and $-19 \%$ (for pure $C_{4}$ ) was used to visualize plant ecology during sample deposition. The $\delta^{13} C$ of $n$-alkanes vary between $-29 \%$ and $-39 \%$ in extant $C_{3}$ plants and $-14 \%$ and $-26 \%$ in $C_{4}$ vegetation. VPDB Vienna Pee-Dee Belemnite. b-f Graphs show relative abundance of each $n$-alkane compound (grey bars), their $\delta^{13} \mathrm{C}$ values (black circles), and average chain length $(A C L)$ of $C_{25}-C_{35}$ carbon homologue. Roman numerals indicate provenance in the stratigraphic column from bottom to top, and these are individual samples, not composite. The placement of each sample along the soil/plant gradient is based on the obtained weighted average for each sample.

A sixth Oldowan cluster was located near a meandering stream within a multi-storey channel belt prograding into the lake, positioned $3 \mathrm{~m}$ beneath Tuff IA ( 2 Ma) and uncovered in trench no. 2 (Figs. 1, 2f, 3, and 5). Fauna does not show marks of hominin processing (Supplementary Note 1). It comprises bovids, suids, equids, large mammals, and Plio-
Pleistocene cercopithecines that feed in grassy environments (cf. Theropithecus oswaldi) ${ }^{44,45}$ as well as perennial water indicators (Chelonia, Crocodylus, and Hippopotamus) (Supplementary Table 4). Phytoliths show woody dicots and grasses booming and busting cyclically ${ }^{46}$, while grassland encroachment on woodlands occurred twice (Supplementary Fig. 5b). 

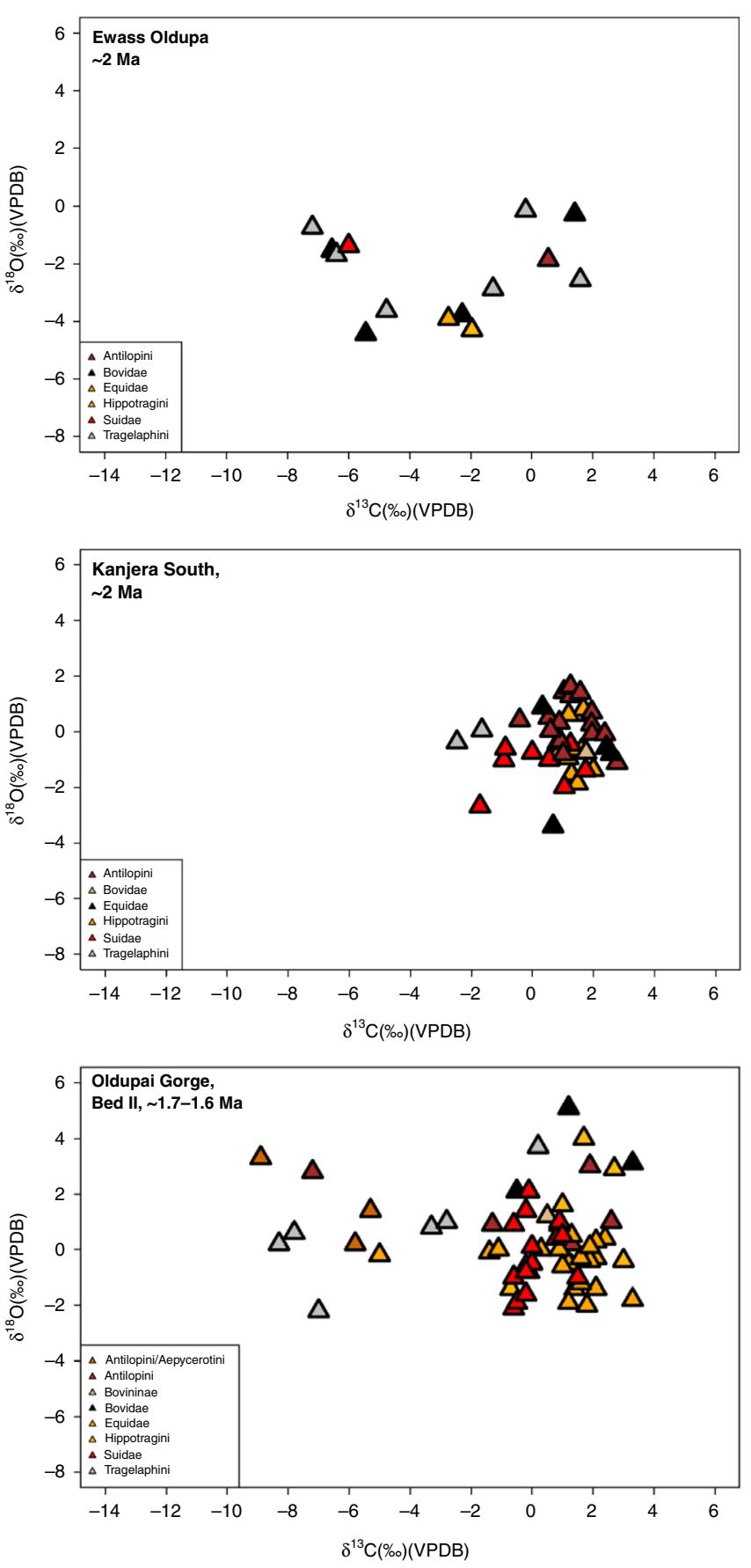

Fig. 8 Stable carbon $(\delta 13 \mathrm{C})$ and oxygen $(\delta 180)$ measurements of animal teeth from Ewass Oldupa (below Tuff IA) compared to contemporaneous and younger fossil datasets ${ }^{\mathbf{1 4}, 75}$. A Mann-Whitney-Wilcoxon test shows significant difference in $\delta 13 C[W=215,<0.05(0.004)]$. There is also $\delta 180$ distinction: $[W=92,<0.05(0.000)]$. Overall, the results suggest that the period 2.0-1.9 Ma was wetter than 1.8-1.6 Ma. Note: only data from the same families of taxa have been included in the comparison.

Isotopic $n$-alkane $\left(\mathrm{C}_{29} \mathrm{C}_{31} \mathrm{C}_{33}\right)$ values for Upper Bed I from regressive lakeshores and small streams between Tuff IA-IB show open woodland with mixed $\mathrm{C}_{3}-\mathrm{C}_{4}$ habitats (Figs. 1 and $7 \mathrm{a}, \mathrm{d}-\mathrm{f}$ ) in a stratigraphic position equivalent to that of the oldest Homo habilis in the Eastern basin ${ }^{30}(\mathrm{OH} 24)$. The succession of Oldowan occupations ends with artefacts from a lakeshore context sandwiched between Tuff IB and IC (1.848/1.832 Ma), in a position and sedimentary environment that on the Western lakeshore is a counterpart to Level $22 \mathrm{Zinj}^{23,24,41,47}$, while still $2 \mathrm{~m}$ below $\mathrm{OH} 65^{21}$ (Fig. 1), as uncovered in trench no. 6. Pollen grains express a treeless, grassless, hyper-xeric steppe dominated by Asteraceae in cohort with Lamiaceae/Convolvulaceae and Rutaceae scrub (Fig. 6o) immediately underneath the Ng'eju Tuff, correlative with a mudstone/calcareous horizon over $\mathrm{OH} 65^{22,48}$.

\section{Discussion}

Ewass Oldupa is a high-resolution, multi-episode, early Oldowan stratified site that precedes and straddles Bed I. This site holds Oldupai's oldest evidence for hominin cultural remains associated with habitats from post volcanic disturbance and thus early examples of adaptation to major geomorphic and ecological transformations. The earliest Oldowan tools appear immediately after the deposition of the Naabi ignimbrite, and they are associated with a stacked fluvial series composed of mafic tephra (Fig. 1). Therein, cross-stratified sandstone and an overall upward fining capped by siltstone shows that humans provisioned near meandering rivers. This episodic exploitation of fluvial environments precedes that of the unstable surfaces characteristic of younger CFCT horizons ${ }^{39}$. Large lithic and faunal assemblages from the contact between the topmost CFCT and lowermost Bed I, together with a wide range of vegetation proxies, mark the onset of lacustrine occupation in the basin, which precedes the emplacement of Tuff IA. The Oldowan toolkits from this time intersect earlier and contemporaneous technologies from Ethiopia and Kenya, while advancing tool types such as the spheroid commonly seen in younger assemblages ${ }^{24}$. If these stone tools drove provisioning amidst unpredictable environments, it was via a generalist strategy 49,50 for a variety of tasks that did not include defleshing animal carcasses, as shown by a lack of human modified fauna.

In conclusion, the earliest Oldupai hominins occupied heterogeneous unstable environments. Sedimentary, chemical, and vegetation data indicate that early Oldowan hominins pioneered a rapid occupation of geo-settings undergoing drastic changes in hydrological resource distribution and structure, and supporting uneven floras. The evidence uncovered is of periodic, recurrent land use across a subset of environments punctuated with times when there is no evidence of hominin activity. Our work reveals early Oldowan stone tools in diverse physical environments, with indications that these environments both changed significantly over space and time. In addition, Oldowan groups utilised disturbance environments-a finding that is unique for this period and depicts complex behavior among early Pleistocene hominins. The ability to exploit diverse biomes enabled hominins to expand beyond Africa. This behavioral flexibility and adaptive suite materialized in the absence of controlled fire, amid large predators, and can be interpreted as a predictor of the invasiveness that facilitated early Homo's global dispersal.

\section{Methods}

Biomarkers. Dry, homogenized sediment was PSE extracted (Büchi Speed Extractor E-916) in three 10 min cycles in 9:1 (v:v) DCM:MeOH at $100^{\circ} \mathrm{C}$ and 103 bar/1500 psi. Neutral, non-polar hydrocarbons were separated from total lipid extracts by Aminopropyl column chromatography using 2:1 DCM:IPOH. Normal $(n-)$ alkanes were then separated from the neutral fraction using silver nitrateinfused silica gel column chromatography using Hexane. Gas chromatography (GC) analysis was performed using an 7890B (Agilent) and HP-5 column (Agilent $30 \mathrm{~m}$ length, $0.25 \mathrm{~mm}$ i.d., and $0.25 \mu \mathrm{m}$ film) with a $5977 \mathrm{~A}$ MSD. Samples were injected at $250^{\circ} \mathrm{C}$ in splitless mode and the oven temperature programmed from $60^{\circ} \mathrm{C}$ ( 1 min hold) to $150^{\circ} \mathrm{C}$ at $10^{\circ} \mathrm{C} /$ minute, then to $320^{\circ} \mathrm{C}$ at $6{ }^{\circ} \mathrm{C} /$ minute (10 min hold). The Mass Spectrometry (MS) source was operated at $230^{\circ} \mathrm{C}$ with $70 \mathrm{eV}$ and a fullscan rate of $\mathrm{m} / \mathrm{z} 50-550$. Plant wax $n$-alkanes were identified by comparing mass spectra and retention time with an external standard mixture $\left(\mathrm{C}_{21}-\mathrm{C}_{40}\right)$.

Isotope-ratio MS Compound-specific $\delta^{13} \mathrm{C}$ values were analysed by 7890B GC (Agilent) with a HP-5 capillary column (Agilent) operated in split mode coupled to 


\begin{tabular}{|c|c|c|c|c|c|}
\hline 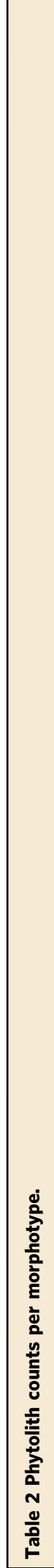 & 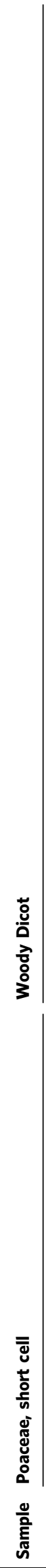 & 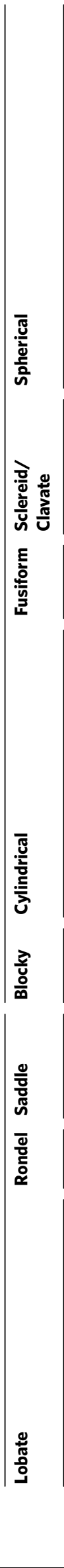 & \begin{tabular}{|l} 
ஸे \\
- \\
$\mid \begin{array}{l}3 \\
1\end{array}$
\end{tabular} & 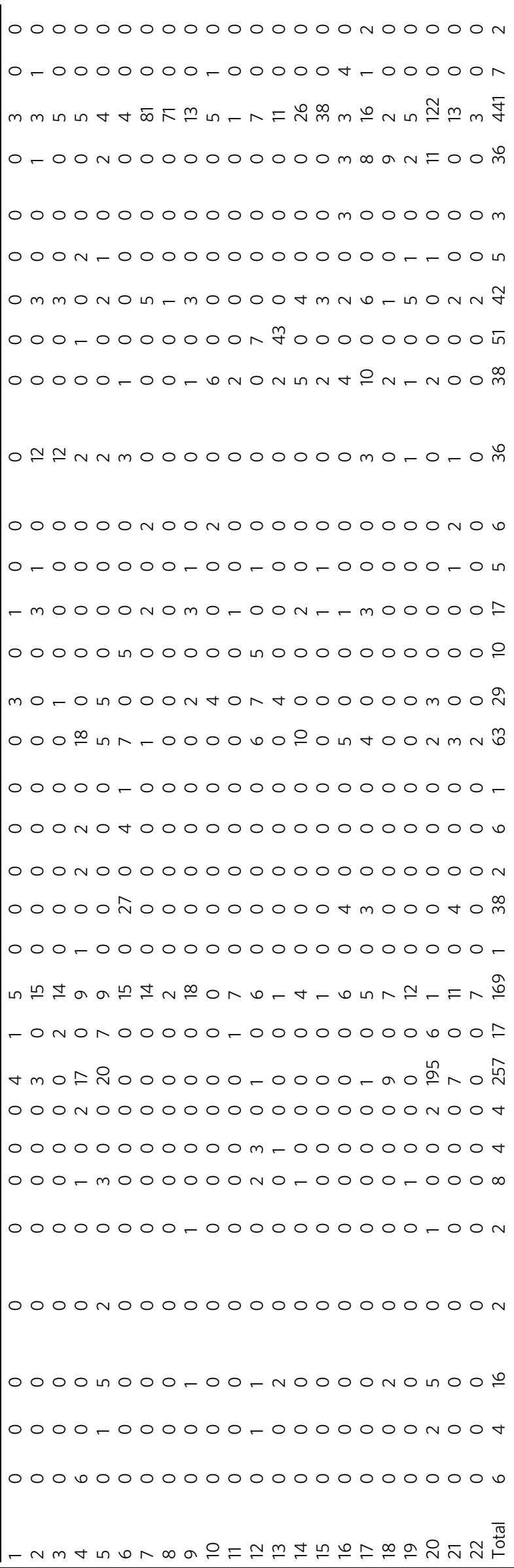 & 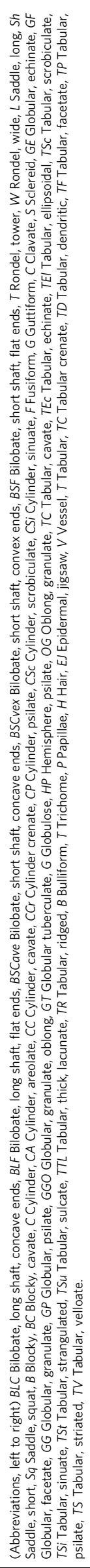 \\
\hline
\end{tabular}


a Elementar Isoprime AnthrovisION Mass Spectrometer by an Elementar GC5 furnace system interface operating at $850^{\circ} \mathrm{C}$. Oven temperature was programmed from $60^{\circ} \mathrm{C}\left(1 \mathrm{~min}\right.$ hold) to $150^{\circ} \mathrm{C}$ at $10^{\circ} \mathrm{C} /$ minute, then to $320^{\circ} \mathrm{C}$ at $6{ }^{\circ} \mathrm{C} /$ minute (10 min hold). Helium was the carrier gas with a constant flow of $1.1 \mathrm{~mL} / \mathrm{min}$. Accuracy of $\delta^{13} \mathrm{C}$ values were evaluated against an international standard laboratory mixture (Indiana B4, Arndt Schimmelmann, University of Indiana) injected at the beginning and end of each sample set. The standard deviation of the $n$-alkane working standard was $\leq 0.5 \%$. Isotopic ratios are expressed as $\delta^{13} \mathrm{C}$ values in per mil relative to the Vienna Pee Dee Belemnite (VPDB) standard.

Energy dispersive X-ray fluorescence. Quartzite artefacts $(n=24)$ were individually sonicated $(10 \mathrm{~min} ; 40 \mathrm{kHz})$ followed by chemical characterisation using EDXRF (Thermo Scientific ARL QUANT'X; end window bremsstrahlung; Rh target X-ray tube $50 \mathrm{~W} ; 76 \mu \mathrm{m}$ beryllium window; $4-50 \mathrm{kV}$; Edwards RV8 vacuum pump). Each analytical run $(n=5)$ included the USGS RGM-2 reference standard for instrument calibration. The targeted elements included eight major oxides $\left(\mathrm{SiO}_{2}, \mathrm{TiO}_{2}, \mathrm{Al}_{2} \mathrm{O}_{3}, \mathrm{Fe}_{2} \mathrm{O}_{3}, \mathrm{MnO}, \mathrm{MgO}, \mathrm{CaO}\right.$, and $\left.\mathrm{K}_{2} \mathrm{O}\right)$ and 10 trace elements $(\mathrm{Cu}$, $\mathrm{Zn}, \mathrm{Rb}, \mathrm{Sr}, \mathrm{Y}, \mathrm{Zr}, \mathrm{Nb}, \mathrm{Ba}, \mathrm{Pb}$, and $\mathrm{Th}$ ). X-ray intensities were automatically converted to concentration estimates (major oxides $=w t \%$; trace elements $=\mathrm{ppm}$ ) using a least-squares calibration line ratioed to the Compton scatter for each element based on international reference standards (AGV-2, BCR-2, BHVO-2, BIR-1a, GSP-2, JR-1, JR-2, QLO-1, RGM-2, SDC-1, STM-2, TLM-1, and W-2a). Concentration estimates were normalised according to the USGS RGM-2 reference standard using Min-Max scaling, with each value rescaled to range $[0,1]$. The same analytical conditions and data treatment methods were implemented for quartzite geological samples $(n=125)$ from five outcrops, which constitute the reference collection used for comparative analyses ${ }^{51,52}$. Data exploration and Linear Discriminant Analysis of the normalised chemical data were performed in RStudio using 14 packages ${ }^{51,52}$.

Excavation. Location of materials was recorded on a Leica TS 09 during excavation. Materials were placed within an $X-Y$ Cartesian system, with $Z$-values also recorded, prior to being individually labelled and bagged. Sediments from each trench were dry-sieved $(0.5 \mathrm{~cm}$ mesh). Identification and $X Y Z$ coordinates were exported to a database. This field database was the matrix for techno-typological classification, taxonomy, taphonomy, and spatial analysis. 3D-registered data was $X Y$-plotted using ArcMap10.7, with $X Z$ and $Y Z$ projections performed N-S and $\mathrm{E}-\mathrm{W}$. Kernel density analysis ( search radius $=25 \mathrm{~cm}$ ) was applied to $X Y$ data.

Fauna. Elements $>2 \mathrm{~cm}$ were studied. For taxonomic identification, we consulted the Smithsonian Institution's digital archive of mammals from East Africa ${ }^{53}$, an osteological manual ${ }^{54}$, an established museum reference collection directly available to us at IPHES (Tarragona, Spain), as well as specialised faunal literature on Early Pleistocene fossils ${ }^{55}$. Surface modifications were noted for all specimens with cortex. The specimens were then studied under a stereomicroscope (Optech HZ, 10-60x). Skeletal profiles were created using the values for the number of identified specimens (NISP). Size class classification ${ }^{56-58}$ was applied where no higher order classification could be made. Minimum number of elements (MNE) was calculated based on NISP, with frequency, portions, size, and side under analysis being noted ${ }^{59}$. MNE portions were used to standardise minimum animal units $(\% \mathrm{MAU})^{60}$. A correlation coefficient for MAU percentage and bone mineral density ${ }^{61}$, considering the MNE of each portion of all elements among ungulates. The age of a specimen was stated where possible, with "unknown" used otherwise. Fracture patterns for long and flat bones were noted ${ }^{62}$

Mineral geochemistry. Composition of phenocrysts was determined by electron microprobe analysis. Preliminary petrographic analysis of polished thin sections used cross-polarizing, petrographic microscope to identify phenocryst abundance, sorting, degree of alteration, and suitability for analysis. Samples were coated with carbon and analyzed using the JEOL JXA-8200 electron microprobe. Electron microprobe beam was operated at a current of $8 \mu \mathrm{A}$ and a voltage of $15 \mathrm{kV}$ and a beam diameter of $11 \mathrm{~mm}$. A combination of brightness from BSE images and EDS was used to identify potential mineral grains to analyze. Where possible, a minimum of 10 grains were analyzed per sample per mineral (30-point/sample). Microprobe calibration standards for feldspar grains were orthoclase and albite, standards for augite/clinopyroxene grains were $\mathrm{Cr}$-augite and hornblende, and ilmenite was used to calibrate for oxide grains. Effort was made to analyze grains that were contained within glass or within pumiceous material. Mineral grains were analysed at random to prevent bias. $\mathrm{Wt} \%$ totals for feldspar and pyroxene analyses less than $96 \%$ or greater than $102 \%$ were excluded from the final data, as were titanomagnetite grains with totals less than $90 \%$.

Phytolith analysis. Samples $(3 \mathrm{~g})$ were mixed with $0.1 \%$ sodium hexametaphosphate $\left(\mathrm{NaPO}_{3}\right)_{6}$ and sonicated $(5 \mathrm{~min})$. Orbital shaking was performed overnight $(200 \mathrm{rpm})$. After clay dispersal, $3 \mathrm{~N}$ hydrochloric $(\mathrm{HCl})$ and nitric acids $\left(\mathrm{HNO}_{3}\right)$ plus hydrogen peroxide $\left(\mathrm{H}_{2} \mathrm{O}_{2}\right)$ was applied. Sodium polytungstate $\left(3 \mathrm{Na}_{2} \mathrm{WO}_{4}\right.$. $9 \mathrm{WO}_{3} \cdot \mathrm{H}_{2} \mathrm{O}$ ) (Poly-Gee) at specific gravity 2.4 separated out phytoliths. Rinsing and centrifugation was done at $3000 \mathrm{rpm}$ for $5 \mathrm{~min}$. Aliquot $(0.001 \mathrm{~g})$ was mounted on microscope slide with Entellan New (cover: $20 \times 40 \mathrm{~mm}=$ inspected area).
System microscopy was at 40x (Olympus BX41, Motic BA410E). Minimum of 200 phytoliths were counted where possible, or until sample extinction. The referential included several African ecoregions ${ }^{46,63-68}$, and past work at Oldupai Gorge ${ }^{43,69}$ Archaeological samples were compared to a baseline of 29 plant species and 35 soils from Acacia-Commiphora woodland mosaics from the study area, using general and diagnostic approaches to reconstruct physiognomy and plant cover rank through their phytolith signal ${ }^{46}$. Classification nomenclature followed ref. 70 .

Pollen and microcharcoal. Protocol was adapted from ref. 71 . Sample $(2 \mathrm{~mL})$ was mixed with $3 \%$ sodium hexametaphosphate $\left(\mathrm{NaPO}_{3}\right)_{6}$ in waterbath $\left(90^{\circ} \mathrm{C}\right)$ for 30 min and mechanically agitated over several days. Lycopodium spore tables were added to calculate pollen and microcharcoal concentrations. Samples settled and decanted $(<2 \mu \mathrm{m})$, followed by sieving $(>125 \mu \mathrm{m})$. Separation of pollen and charcoal was done using gentle mechanical agitation over several days followed by heavy liquid separation using lithium heteropolytungstate at specific gravity 2.0. Acetolysis was achieved through 9:1 mixture of $\mathrm{C}_{4} \mathrm{H}_{6} \mathrm{O}_{3}$ to $\mathrm{H}_{2} \mathrm{SO}_{4}$ and $10 \% \mathrm{HCl}$. The samples were mounted on microscope slide with glycerol (cover: $22 \times 40 \mathrm{~mm}$ $=$ inspected area). System microscopy was done at $25 \mathrm{x}, 40 \mathrm{x}, 63 \mathrm{x}$. Minimum of 350 pollen grains and 200 microcharcoal were counted.

Stable carbon and oxygen isotope analysis of faunal dental enamel. Specimens selected all had excellent preservation conditions, and no weathered or fragmented dental specimens were considered. Teeth were cleaned using air-abrasion. Sample of enamel powder $(6 \mathrm{mg})$ was taken from buccal edge using diamond-tipped burr drill. It was washed in $1.5 \% \mathrm{NaClO}$ for $60 \mathrm{~min}$, rinsed, then centrifuged. It was then washed with acetic acid $(0.1 \mathrm{M})$ for $10 \mathrm{~min}$ and rinsed. Residue was lyophilised for $24 \mathrm{~h}$, then set to react with $\mathrm{H}_{3} \mathrm{PO}_{4}$ and gases were measured for stable carbon and oxygen ratios using GasBench II (Thermo) coupled with Delta V Advantage MS (Thermo). Values were compared against International Standards: IAEA-603 $\left(\delta^{13} \mathrm{C}=2.5 ; \delta^{18} \mathrm{O}=-2.4\right)$; IAEA-CO-8 $\left(\delta^{13} \mathrm{C}=-5.8 ; \delta^{18} \mathrm{O}=-22.7\right)$; USGS44 $\left(\delta^{13} \mathrm{C}=-42.2\right)$, and in-house standard MERCK $\left(\delta^{13} \mathrm{C}=-41.3 ; \delta^{18} \mathrm{O}=-14.4\right)$. Measurement error of MERCK standard $c$ was $\pm 0.1 \%$ for $\delta^{13} \mathrm{C}$ and $\pm 0.2 \%$ for $\delta^{18} \mathrm{O}$. Overall precision of measurements through repeat extracts from an inhouse bovid tooth enamel standard $c$ was $\pm 0.2 \%$ for $\delta^{13} \mathrm{C}$ and $\pm 0.3 \%$. Obligate or non-obligate drinking status was inferred from the range of $\delta^{18} \mathrm{O}$ as per references $^{72-74}$.

Stone tools. All specimens were measured and weighed, with attributes recorded in database. Technological classes such as core, core fragment, flake, broken flake, flake fragment with a platform, percussive material, retouched piece, and tools were distinguished. Knapping methods were classified according to faciality (noting the number of surfaces exploited) and polarity (direction of exploitation from a striking platform). The following core reduction methods were observed: (i) multipolar-multifacial: cores with four or more surfaces exploited in at least four different directions; (ii) unipolar-longitudinal: cores with a single surface exploited, unidirectionally; (iii) orthogonal-bifacial: cores with two opposed surfaces knapped, unidirectionally; (iv) centripetal-bifacial: cores with two exploitation surfaces organized by a horizontal plane, each side with at least three centripetal removals; (v) centripetal-unifacial: cores with one surface exploited and at least three centripetal extractions; (vi) bipolar-on-anvil: cores with evidence of placement on passive surface; (vii) bipolar-unifacial: cores with one surface exploited bidirectionally. Multivariate ordination utilized variables from ref. ${ }^{15}$ through Palaeotological Statistics software. We normalized variables. The first three components of the PCA explain $80.1 \%$ of the variance.

Reporting summary. Further information on research design is available in the Nature Research Reporting Summary linked to this article.

\section{Data availability}

All data are available in the main text and the supplementary materials. Materials are to be deposited with the National Museums of Tanzania.

Received: 27 July 2020; Accepted: 12 November 2020; Published online: 07 January 2021

\section{References}

1. Toth, N. \& Schick, K. An overview of the cognitive implications of the Oldowan Industrial Complex. Azania 53, 3-39 (2018).

2. Pobiner, B. L., Rogers, M. J., Monahan, C. M. \& Harris, J. W. New evidence for hominin carcass processing strategies at $1.5 \mathrm{Ma}$, Koobi Fora, Kenya. J. Hum. Evol. 55, 103-130 (2008).

3. Domínguez Rodrigo, M. Meat eating by early hominids at the FLK 22 Zinjanthropus site, Olduvai Gorge, Tanzania: an experimental approach using cut mark data. J. Hum. Evol. 33, 669-690 (1997). 
4. Sahnouni, M. et al. 1.9-million- and 2.4-million-year-old artefacts and stone tool-cutmarked bones from Ain Boucherit, Algeria. Science 362, 1297-1301 (2018).

5. Ferraro, J. V. et al. Earliest archaeological evidence of persistent hominin carnivory. PLoS One 8, e62174 (2013).

6. Braun, D. R. et al. Early hominin diet included diverse terrestrial and aquatic animals 1.95 MA in East Turkana, Kenya. Proc. Natl Acad. Sci. 107, 10002-10007 (2010).

7. Zhu, Z. et al. Hominin occupation of the Chinese Loess Plateau since about 2.1 million years ago. Nature 559, 608-612 (2018).

8. Lordkipanidze, D. et al. A complete skull from Dmanisi, Georgia, and the evolutionary biology of early. Homo. Sci. 342, 326-331 (2013).

9. Ferring, R. et al. Earliest human occupations at Dmanisi (Georgian Caucasus) dated to 1.85-1.78 Ma. Proc. Natl Acad. Sci. 108, 10432-10436 (2011).

10. Asfaw, B. et al. Fejej: a new paleoanthropological research area in Ethiopia. $J$. Hum. Evol. 21, 137-143 (1991)

11. Barksy, D. et al. The Early Oldowan stone-tool assemblage from Fejej FJ-1A. Ethiop. J. Afr. Archaeol. 9, 207-224 (2011).

12. Kimbel, W. et al. Late Pliocene Homo and Oldowan tools from the Hadar formation (Kada Hadar Member), Ethiopia. J. Hum. Evol. 31, 549-561 (1996).

13. Patterson, D. B. et al. Ecosystem evolution and hominin paleobiology at East Turkana, northern Kenya between 2.0 and 1.4 Ma. Palaeogeogr. Palaeoclimatol. Palaeoecol. 481, 1-13 (2017).

14. Plummer, T. W. et al. Oldest evidence of toolmaking hominins in a grasslanddominated ecosystem. PLoS One 4, e7199 (2009).

15. Braun, D. R. et al. Earliest known Oldowan artifacts at $>2.58$ Ma from LediGeraru, Ethiopia, highlight early technological diversity. Proc. Natl Acad. Sci. 116, 11712-11717 (2019).

16. Plummer, T. Flaked stones and old bones: biological and cultural evolution at the dawn of technology. Yearb. Phys. Anthropol. 47, 118-164 (2004).

17. Plummer, T. W. \& Bishop, L. C. Oldowan hominin behaviour and ecology at Kanjera South, Kenya. J. Anthropol. Sci. 94, 1-12 (2016).

18. Stanistreet, I. G. et al. New Olduvai Basin stratigraphy and stratigraphic concepts revealed by OGCP cores into the Palaeolake Olduvai depocentre, Tanzania. Palaeogeogr. Palaeoclimatol. Palaeoecol. volume 554 (2020).

19. Bobe, R. et al. Faunal change, environmental variability and late Pliocene hominin evolution. J. Hum. Evol. 42, 475-497 (2002).

20. Harrison, T. Paleontology and Geology of Laetoli: Human Evolution in Context Vol. 1 (2011). Springer.

21. Plummer, T. W. \& Finestone, E. In Rethinking Human Evolution (ed Schwartz, J.) (MIT Press, 2017). Chapter 13.

22. Blumenschine, R. J. et al. Late Pliocene Homo and hominid land use from western Olduvai Gorge, Tanzania. Science 299, 1217-1221 (2003).

23. Hay, R. The Geology of Olduvai Gorge (Univ. of California Press, 1976).

24. Leakey, M. D. Olduvai Gorge: Excavations in Beds I and II, 1960 - 1963 Vol. 3 (Cambridge Univ. Press, 1971).

25. Deino, A. L. ${ }^{40} \mathrm{Ar} /{ }^{39} \mathrm{Ar}$ dating of Bed I, Olduvai Gorge, Tanzania, and the chronology of early Pleistocene climate change. J. Hum. Evol. 63, 251-273 (2012).

26. McHenry, L. J. A revised stratigraphic framework for Olduvai Gorge Bed I based on tuff geochemistry. J. Hum. Evol. 63, 284-299 (2012).

27. McHenry, L. J. et al. Tuff fingerprinting and correlations between OGCP cores and outcrops for Pre-Bed I and Beds I/II at Olduvai Gorge, Tanzania. Palaeogeogr. Palaeoclimatol. Palaeoecol. 548, 109630 (2020).

28. Habermann, J. M. et al. Discrimination, correlation, and provenance of Bed I tephrostratigraphic markers, Olduvai Gorge, Tanzania, based on multivariate analyses of phenocryst compositions. Sediment. Geol. 339, 115-133 (2016).

29. Stanistreet, I. G. et al. Palaeosalinity and palaeoclimatic geochemical proxies (elements $\mathrm{Ti}, \mathrm{Mg}, \mathrm{Al}$ ) vary with Milankovitch cyclicality (1.3 to $2.0 \mathrm{Ma}$ ), OGCP cores, Palaeolake Olduvai, Tanzania. Palaeogeogr. Palaeoclimatol. Palaeoecol. 546, 109656 (2020).

30. Tobias, P. V. Olduvai Gorge: The Skulls, Endocasts, and Teeth of Homo habilis Vol. 4 (Cambridge Univ. Press, 1991).

31. Stanistreet, I. G. et al. Lahar inundated, modified, and preserved 1.88 Ma early hominin (OH24 and OH56) Olduvai DK site. J. Hum. Evol. 116, 27-42 (2018).

32. Schick, K. \& Toth, N. (eds) The Oldowan: Case Studies into the Earliest Stone Age (Stone Age Institute Press, 2006).

33. Reti, J. S. Quantifying Oldowan stone tool production at Olduvai Gorge, Tanzania. PLoS One 11, e0147352 (2016).

34. Mollel, G. F., Swisher, C. C. III, Feigenson, M. D. \& Carr, M. J. Geochemical evolution of Ngorongoro Caldera, Northern Tanzania: implications for crustmagma interaction. Earth Planet. Sci. Lett. 271, 337-347 (2008).

35. Kondo, R., Childs, C. W., Atkinson, I. A. E. \& Pritchard, T. Opal Phytoliths of New Zealand. (Manaaki Whenua Press, 1994).

36. Sundue, M. Silica bodies and their systematic implications in Pteridaceae (Pteridophyta). Bot. J. Linn. Soc. 161, 422-435 (2009).
37. Chauhan, D. K., Tripathi, D. K., Since, P. \& Tiwari, S. P. Biogenic silica in some Pteridophytes. Bionature 29, 1-9 (2009).

38. Walker, L. R. \& Sharpe, J. M. In Fern Ecology (eds Mehltreter, K., Walker, L.R., \& Sharpe, J.M.) (Cambridge Univ. Press, 2010). Chapter 6.

39. Habermann, J. M. et al. In situ $\sim 2.0 \mathrm{Ma}$ trees discovered as fossil rooted stumps, lowermost Bed I, Olduvai Gorge, Tanzania. J. Hum. Evol. 90, 74-87 (2016).

40. Albert, R. M., Bamford, M. K. \& Esteban, I. Reconstruction of ancient palm vegetation landscapes using a phytolith approach. Quat. Int. 369, 1-16 (2014).

41. Uribelarrea, D. et al. Geo-archaeological and geometrically corrected reconstruction of the 1.84 Ma FLK Zinj paleolandscape at Olduvai Gorge, Tanzania. Quat. Int. 322-323, 7-31 (2014).

42. Magill, C. R., Ashley, G. M., Domínguez-Rodrigo, M. \& Freeman, K. H. Dietary options and behavior suggested by plant biomarker evidence in an early human habitat. Proc. Natl Acad. Sci. 113, 2874-2879 (2016).

43. Ashley, G. M. et al. Paleoenvironmental and paleoecological reconstruction of a freshwater oasis in savannah grassland at FLK North, Olduvai Gorge, Tanzania. Quat. Res. 74, 333-343 (2010).

44. Jablonski, N. G. \& Leakey, M. G. Koobi Fora Research Project: The Fossil Monkeys Vol. 6 (The California Academy of Sciences, 2008)

45. Jolly, C. J. The classification and natural history of Theropithecus (Simopithecus) (Andrews, 1916), baboons of the African Plio-Pleistocene. Bull. Br. Mus. Nat. Hist. Geol. 22, 1-123 (1972).

46. Mercader, J. et al. Soil and plant phytoliths from the Acacia-Commiphora mosaics at Oldupai Gorge (Tanzania). PeerJ 7, e8211 (2019).

47. Leakey, L. S. B. A new fossil from Olduvai. Nature 184, 491-494 (1959).

48. Sikes, N. E. \& Ashley, G. M. Stable isotopes of pedogenic carbonates as indicators of paleoecology in the Plio-Pleistocene (upper Bed I), western margin of the Olduvai Basin, Tanzania. J. Hum. Evol. 53, 574-594 (2007).

49. Potts, R. Variables versus models of early Pleistocene hominin land use. $J$. Hum. Evol. 27, 7-24 (1994).

50. Potts, R. Hominin evolution in settings of strong environmental variability. Quat. Sci. Rev. 73, 1-13 (2013).

51. Soto, M. et al. Fingerprinting of quartzitic outcrops at Oldupai Gorge. Tanzan. J. Archaeol. Sci. Rep. 29, 102010 (2020).

52. Soto, M. et al. Systematic sampling of quartzite in sourcing analysis: intraoutcrop variability at Naibor Soit, Tanzania (part I). Archaeol. Anthropol. Sci. 12, 1-14 (2020).

53. Assefa, $\mathrm{Z}$ Digital archive of East African mammals. (Smithsonian Institution, Washington, 2006).

54. Pales, L. \& Lamert, P. Atlas osteóologique: pour servir à l'identification des mammifères du Quaternaire. Les membres Herbivores. (Centre National de la Recherche Scientifique, 1971).

55. Jablonski, N. G. \& Leakey, M. G. Koobi For a Research Project: The Fossil Monkeys Vol. 6 (California Academy of Sciences, 2008).

56. Brain, C. K. Some suggested procedures in the analysis of bone accumulations from southern African Quaternary sites. Ann. Transv. Mus. 29, 1-5 (1974).

57. Brain, C. K. The Hunters or the Hunted? An Introduction to African Cave Taphonomy (Univ. of Chicago Press, 1981).

58. Klein, R. G. The mammalian fauna of the Klasies River Mouth sites, Cape Province, South Africa. S. Afr. Archaeol. Bull. 31, 75-98 (1976).

59. Klein, R. G. \& Cruz-Uribe, K. The Analysis of Animal Bones from Archaeological Sites (Univ. of Chicago Press, 1984).

60. Binford, L. R. The Faunal Remins from Klasies River Mouth. (Academic Press, 1984).

61. Lam, Y. M. et al. Intertaxonomic variability in patterns of bone density and the differential representation of Bovid, Vervid, and Equid elements in the archaeological record. Am. Antiq. 64, 343-362.

62. Villa, P. \& Mahieu, E. Breakage patterns of human long bones. J. Hum. Evol. 21, 27-48 (1991).

63. Runge, F. The opal phytolith inventory of soils in Central Africa - Quantities, shapes, classification, and spectra. Rev. Palaeobot. Palyno. 107, 23-53 (1999).

64. Collura, L. V. \& Neumann, K. Wood and bark phytoliths of West African woody plants. Quat. Int. 43, 142-159 (2017).

65. Fahmy, A. G. Diversity of lobate phytoliths in grass leaves from the Sahel region, West Tropical Africa: Tribe Paniceae. Plant Syst. Evol. 270, 1-23 (2008).

66. Mercader, J., Bennett, T., Esselmont, C., Simpson, S. \& Walde, D. Phytoliths in woody plants from the Miombo woodlands of Mozambique. Ann. Bot. 104, 91-113 (2009).

67. Mercader, J. et al. Poaceae phytoliths from the Niassa Rift, Mozambique. J. Archaeol. Sci. 37, 1953-1967 (2010).

68. Mercader, J., Bennett, T., Esselmont, C., Simpson, S. \& Walde, D. Soil phytoliths from miombo woodlands in Mozambique. Quat. Res. 75, 138-150 (2011).

69. Albert, R. M., Bamford, M. K. \& Cabanes, D. Taphonomy of phytoliths and macroplants in different soils from Olduvai Gorge (Tanzania) and the 
application to Plio-Pleistocene palaeoanthropological samples. Quat. Int. 148, 78-94 (2006).

70. Madella, M., Alexandre, A. \& Ball, T. International code for phytolith nomenclature 1.0. Ann. Bot. 96, 253-260 (2005).

71. Bennett, K. D. \& Willis, K. J. In Tracking Environmental Change using Lake Sediments: Terrestrial, Algal, and Siliceous Indicators Vol. 3 (eds Smol, J.P., Birks, H.J.B. \& Last, W.M.) (Springer, 2001). Chapter 2.

72. Levin, N. E., Cerling, T. E., Passey, B. H., Harris, J. M. \& Ehleringer, J. R. A stable isotope aridity index for terrestrial environments. Proc. Natl Acad. Sci. 103, 11201-11205 (2006).

73. Blumenthal, S. A. et al. Stable isotope time-series in mammalian teeth: in situ $\delta^{18} \mathrm{O}$ from the innermost enamel layer. Geochim. Cosmochim. Acta 124, 223-236 (2014).

74. Roberts, P. et al. Fossil herbivore stable isotopes reveal middle Pleistocene hominin palaeoenvironment in 'Green Arabia'. Nat. Ecol. Evol. 2, 1871-1878 (2018).

75. Uno, K. T. et al. Large mammal diets and paleoecology across the OldowanAcheulean transition at Olduvai Gorge, Tanzania from stable isotope and tooth wear analyses. J. Hum. Evol. 120, 76-91 (2018).

76. McHenry, L. J. Phenocryst composition as a tool for correlating fresh and altered tephra, Bed I, Olduvai Gorge, Tanzania. Stratigraphy 2, 101-115 (2005).

\section{Acknowledgements}

First, the authors acknowledge the essential contributions to the knowledge presented herein by the Masai communities at Oldupai Gorge. This work was supported by the Canadian Social Sciences and Humanities Research Council under its Partnership Grant Program no. 895-2016-1017. The Tanzania Commission for Science and Technology authorized this work under permit no. 2018-112-NA-2018-36. The Tanzanian Ministry of Natural Resources and Tourism, through its Antiquities Division, granted us permission to carry out this work (14/2017/2018) and authorities at the Ngorongoro Conservation Area allowed us to enter the protected area (BE.504/620/01/53). The export license for the materials presented in this study were obtained from the Antiquities Division (EA.150/ 297/01: 5/2018/2019) and the Tanzanian Executive Secretary from the Mining Commission (00001258). Pam Akuku and Palmira Saladié are supported by AGAUR (project no. 2017 SGR-1040) and the URV (2018PFR-URV-B2-91). Pam Akuku's doctoral program is funded by the Canadian Social Sciences and Humanities Research Council. Nina Jablonsky, Bernard Wood, and Michael Lague assisted us with the identification of cercopithecine remains.

\section{Author contributions}

J.M.: conceptualization, methodology, analysis, investigation, resources, data curation, writing original draft, writing review and editing, visualization, supervision, project administration, funding acquisition; P.A.: analysis, investigation; N.B.: conceptualization, writing review and editing, funding acquisition; R.B.: resources, project administration; P.B.: conceptualization, investigation, resources, project administration; A.C.: analysis, investigation; T.C.: analysis, investigation, writing review and editing; S.C.: analysis, investigation, writing review and editing; A.C.T.: conceptualization, methodology, analysis, investigation, writing review and editing, visualization; P.D.: conceptualization, methodology, analysis, investigation, resources, writing review and editing, visualization, funding acquisition; J.F.: conceptualization, analysis, investigation, writing review and editing, visualization, funding acquisition; K.F.: investigation; S.H.: analysis, investigation, writing review and editing; S.H.: conceptualization, methodology, analysis, investigation, resources, writing review and editing, visualization, funding acquisition; J.I.: investigation; M.I.: investigation, resources, project administration; S.K.: investigation, resources; P.L.: investigation, writing review and editing; A.M.: investigation, resources, project administration; A.M.: investigation; L.O.: investigation, resources; R.P.: analysis, investigation, writing review and editing, visualization; P.R.: analysis, investigation, writing review and editing, visualization; S.R.: analysis, investigation, visualization; P.S.: analysis investigation, visualization; G.S.: writing review and editing, visualization; M.S.: conceptualization, methodology, analysis, investigation, resources, data curation, writing review and editing, visualization, supervision; J.U.: analysis, investigation, writing review and editing, visualization; M.P.: conceptualization, investigation, writing review and editing, visualization, supervision, funding acquisition.

\section{Funding}

Open Access funding enabled and organized by Projekt DEAL.

\section{Competing interests}

The authors declare no competing interests.

\section{Additional information}

Supplementary information is available for this paper at https://doi.org/10.1038/s41467020-20176-2.

Correspondence and requests for materials should be addressed to J.M., S.H. or M.S.

Peer review information Nature Communications thanks the anonymous reviewers for their contribution to the peer review of this work. Peer reviewer reports are available.

Reprints and permission information is available at http://www.nature.com/reprints

Publisher's note Springer Nature remains neutral with regard to jurisdictional claims in published maps and institutional affiliations.

(c) (i) Open Access This article is licensed under a Creative Commons BY Attribution 4.0 International License, which permits use, sharing, adaptation, distribution and reproduction in any medium or format, as long as you give appropriate credit to the original author(s) and the source, provide a link to the Creative Commons license, and indicate if changes were made. The images or other third party material in this article are included in the article's Creative Commons license, unless indicated otherwise in a credit line to the material. If material is not included in the article's Creative Commons license and your intended use is not permitted by statutory regulation or exceeds the permitted use, you will need to obtain permission directly from the copyright holder. To view a copy of this license, visit http://creativecommons.org/ licenses/by/4.0/.

(C) The Author(s) 2021 